\title{
A study on incorporation of transpired solar collector in a novel multifunctional PV/Thermal/Daylighting (PV/T/D) panel
}

\author{
Meng TIAN ${ }^{1}$, Xu YU ${ }^{1}$, Yuehong SU ${ }^{1,}{ }^{*}$, Hongfei ZHENG ${ }^{2}$, Saffa Riffat ${ }^{1}$
}

${ }^{1}$ Department of Architecture and Built Environment, Faculty of Engineering, University of Nottingham, University Park, Nottingham NG7 2RD, UK

${ }^{2}$ School of Mechanical Engineering, Beijing Institute of Technology, Beijing 100081, China

${ }^{*}$ Corresponding author: yuehong.su@nottingham.ac.uk

\begin{abstract}
When a transparent dielectric compound parabolic concentrator (CPC) PV panel is applied as a skylight in atrium, heat rejection from the PV cells results in both low electrical conversion efficiency and unwanted heat to the atrium in summer, which usually causes a common issue of overheating or increased cooling load for façade and atrium buildings. This paper introduces a novel multifunctional PV/Thermal/Daylighting (PV/T/D) system by incorporating a transpired solar collector with the dielectric CPC panel. The thermal performance of system was investigated through simulations by computational fluid dynamics (CFD) software and experiments. Parametric studies were conducted to evaluate the effects on the thermal performance by different design criteria such as approach velocity, plenum height, pitch and diameter of perforation, porosity and solar radiation level. The experiments were taken under both indoor solar simulator and outdoor real sky conditions. Results show that the designed PV/T/D system could largely remove the heat generated on the PV cells so that the higher PV operation efficiency could be achieved. In addition, the design of transparent perforation plate underneath the dielectric CPC panel could largely reduce the heat flux to the atrium space so that the cooling load of atrium could be largely reduced.
\end{abstract}

\section{Graphical abstract}

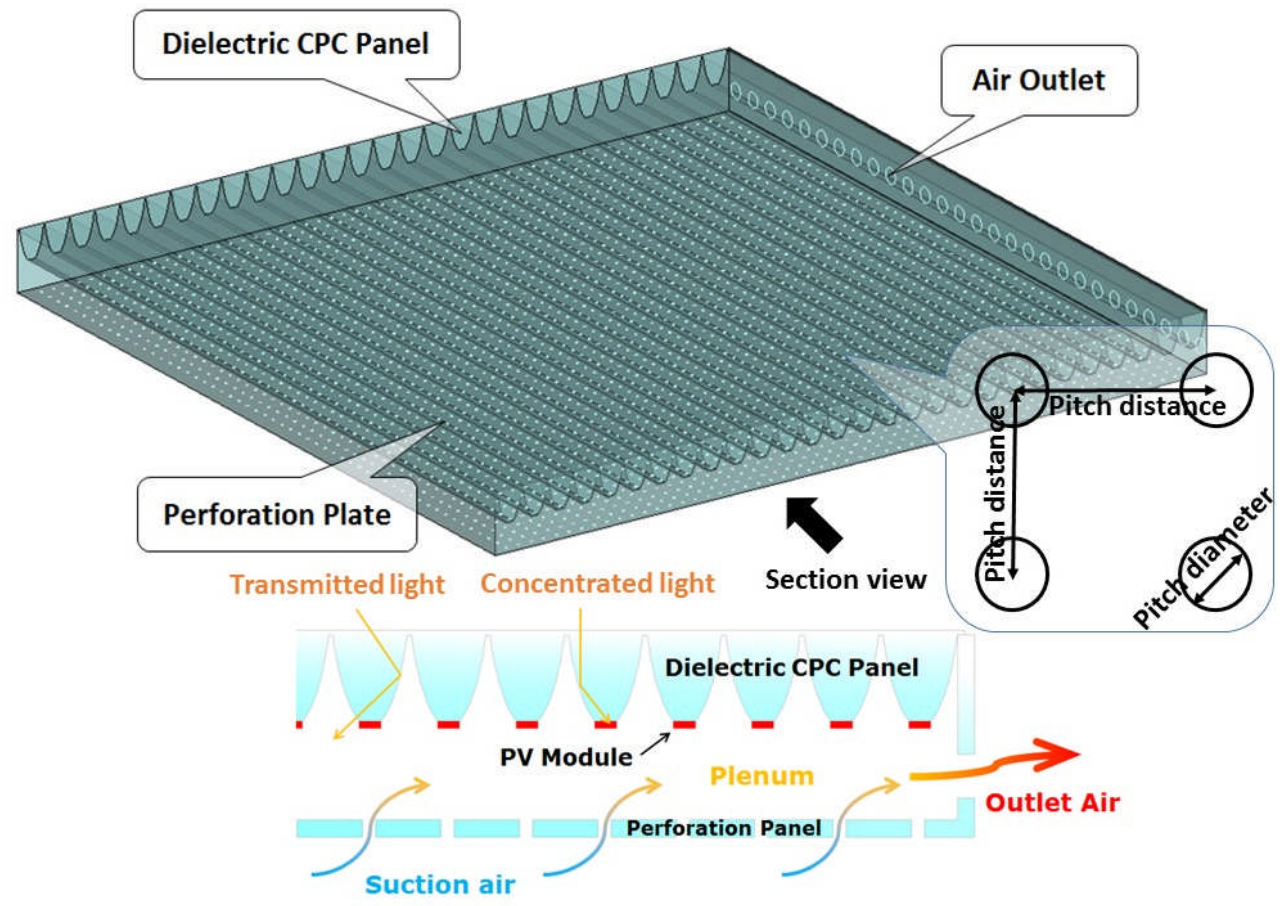




\section{Highlights}

- A multifunctional PV/Thermal/Daylighting panel is proposed.

- The transpired solar collector largely reduce heat gain to the building interior.

- The thermal performance was investigated by simulation and experiment.

- Parametric studies focusing on the effects on thermal performance were conducted.

- The thermal efficiency of this system could range between $40 \%$ and $85 \%$.

\section{Keywords:}

Multifunctional PV/Thermal/Daylighting; miniature dielectric CPC panel; transpired solar collector; CFD simulation; experimental study. 


\section{Introduction}

In order to utilise solar radiation efficiently and reduce the usage of expensive PV material, solar concentrators are usually used to be integrated with the photovoltaic/thermal (PV/T) system. Compound parabolic concentrator (CPC) belonging to nonimaging optics has been regarded as a highly potential and appealing option for solar energy concentration and illumination since mid-1960s (Baranov, 1965, Baranov, 1966, Ploke, 1967, Baranov, 1967, Hinterberger, 1966a, Hinterberger, 1966b, Ploke, 1969, Baranov and Melnikov, 1966). Based on its specific optical structure, CPC has the abilities to both concentrate solar radiation onto its base for PV application and transmit it through its profile for daylighting application, in respect to the incident angle compared to its acceptance angle. Due to its simple construction, it is much easier incorporated in building integrated $\mathrm{PV} / \mathrm{T}$ (BiPV/T). Thus, it has been widely applied in photovoltaic (PV) in the past fifty years. Its potential in daylighting control when it is used as a skylight and building facade has been discovered in recent years as well. However, when the sunlight is concentrated onto the solar cell attached to the base of a CPC, the concentrated heat could also result in the increase of PV cell temperature. Lots of studies indicated that the output power of PV cell is significantly influenced by the operating temperature: one Kelvin increase in operating temperature could cause $0.4 \%-0.65 \%$ power reduction (Radziemska, 2003). Reducing the operating temperature of the PV cell attached to CPC would be crucial in CPC applications.

In the past few decades, the technologies to remove the excessive heat from the PV module developed quickly. The most promising technology is using the cooling fluid such as water or air to extract heat from PV to open loop or closed loop configuration. The extracted heat could be reused for space heating, ventilation or domestic hot water by either direct or indirect means (Athienitis et al., 2011). This type of system is named as hybrid photovoltaic/thermal (PV/T) system. Normally, PV has the ability to convert $6-16 \%$ solar energy into electricity at the temperature of $25^{\circ} \mathrm{C}$, the remaining $80 \%$ of incident solar radiation could be used as heat (Zondag, 2008). Therefore, the PV/T system is regarded as a high-efficiency solar technology due to the dual benefits of simultaneously increasing solar electricity conversion efficiency and comprehensive utilization of solar thermal energy. The total solar energy conversion ratio of PV/T system could reach $60-80 \%$ for different system designs (Naewngerndee et al., 2011, Chow et al., 2009, Bergene and Løvvik, 1995). Among various PV/T systems, the air-based PV/T system using air as a working fluid was the most popular one being studied at the early stage of PV/T technology research, which is due to its easy set-up and low cost on both construction and operation (Abdul Hamid et al., 2014).

Several studies have investigated the performances of various CPC-PV/T systems. Garg and Brogren (Garg and Adhikari, 1999, Brogren et al., 2001) explored the CPC-PV/T system with the concentration ratio of 3 and 4 ; results showed that its thermal and electricity outputs were related to the solar collector length, mass flow rate of air, solar cell density, optical properties of the glazing, reflector, absorber and so forth. Sun and Shi (Sun and Shi, 2010) designed and tested the performance of a single-pass PV/T system integrating CPC. There were fins attached to the back side of PV panel to speed up the heat transfer to the air in chamber. It was found that the maximum short circuit current was higher than twice of the current of standard PV panel. Li et al. took some preliminary researches on a CPC-BiPV/T system with novel static 
incorporated lens-walled CPC (Li et al., 2014, Guiqiang et al., 2014). It was found that the average optical efficiency was up to $83 \%$ when the incident lights were within the half acceptance angle.

The design of a novel CPC-PV/T system that will be introduced in this paper was inspired by the unglazed transpired solar air collector (UTC) which is a well-recognised solar air heating technology. The example applications of UTC include pre-heating ventilation air and heating air for crop drying (Arulanandam et al., 1999). It has been manufactured and widely used for commercial purposes. The efficiency could reach as high as $70 \%$ in real application. In recent years, the novel UTC system integrated with PV or PV/T system was developed and evaluated by several researchers (Athienitis et al., 2011, Naveed et al., 2006). Compared to other types of solar heater, UTC has two main advantages. Firstly, heat loss from the absorber surface could be minimised due to homogenous suction of air through the perforations, which has been proved theoretically in a previous research (Kutscher et al., 1993). Secondly, the initial cost of the system could be reduced as there is no need for a glazing cover, and the combination of high thermal efficiency and low cost of solar collector makes the UTC system achieve the economic performance of 2-10 years payback period (Hall et al., 2011). The state of art review on various research literatures on the performance of UTC system showed that the most critical parameters influencing the UTC system efficiency include absorptivity and emissivity of absorber, surface approach velocity (the volume flow rate per unit area of entire surface), the width of the plenum, pitch layout and porosity, wind velocity and so forth (Shukla et al., 2012). The relationship between these factors and UTC performance is well investigated by researchers using experimental and numerical methods (Leon and Kumar, 2007, Badache et al., 2013).

A dielectric CPC panel integrating PV for skylight application was proposed in our previous study (Yu et al., 2014). This paper will investigate a heat recovery system for the CPC-PV panel to achieve multifunctional PV/Thermal/Daylighting (PV/T/D) applications. The concentrated heat on the PV cell attached on the base of dielectric CPC could result in both low electrical conversion efficiency and transmission of unwanted heat into the atrium in summer. Except generating electricity by PV and providing daylight to atrium, three objectives were put forward for this study according to the level of priority:

1) Prevent the convection heat gain from roof panel to atrium space so that the indoor thermal comfort could be guaranteed.

2) Reduce the operating temperature of PV cell attached to the base of dielectric CPC panel to improve its electrical efficiency.

3) Utilise the removed heat for thermal application such as drying food, air or water preheating.

The design of the whole PV/T/D system will be introduced first in this paper. Then the thermal performance of it will be investigated numerically with the aid of computational fluid dynamics (CFD) software. The heat transfer and air flow through the system are modelled by using commercial software (FLUENT). The parametric studies would be taken to evaluate the influence by some design parameters on the PV/T/D system in terms of several design criteria such as approach velocity, plenum height, pitch and perforation dimension, porosity and solar 
radiation level. Finally, experimental results obtained under solar simulator and real sky would be presented to confirm the feasibility of the designed PV/T/D system.

\section{System design}

The concentrator applied in this study was dielectric compound parabolic concentrator (dCPC) which was investigated in our previous research (Yu et al., 2014). It could concentrate a portion of solar radiation onto the PV cell on its the base and meanwhile transmit the rest for daylighting. Fig. 1 demonstrates the 3D view and section view of the CPC panel which is a $507.2 \mathrm{~mm} * 500 \mathrm{~mm}$ square panel consisting of 28 mini dielectric CPC rods of $21 \mathrm{~mm}$ high. It is worth to mention that the design of the $1.6 \mathrm{~mm}$ wide overhang is for the convenience of installation on the integrating box during the experiment test. The whole panel is made of clear acrylic.

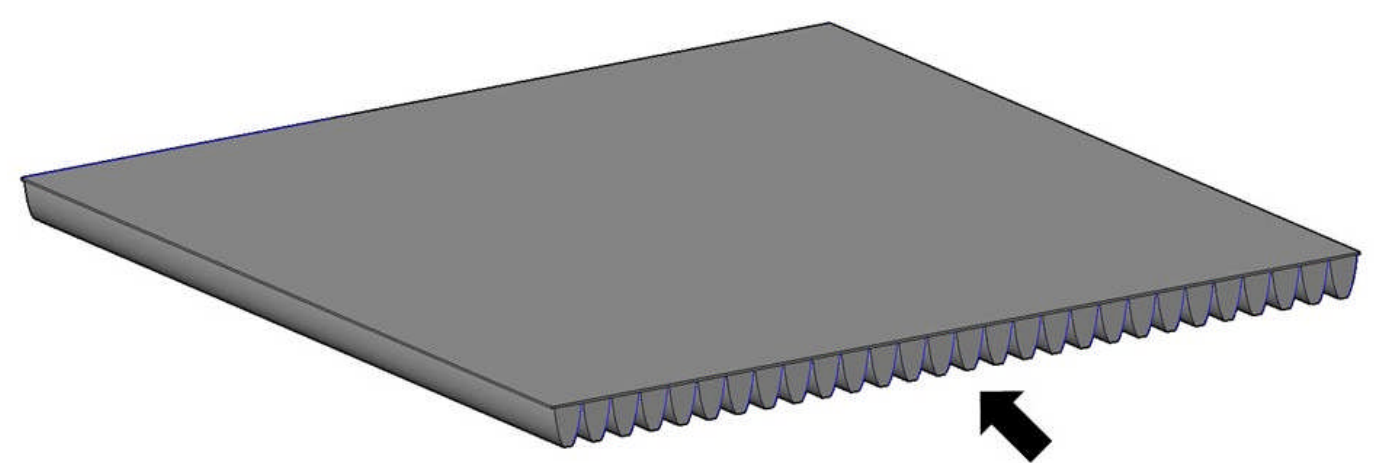

507.2

\section{Section view}

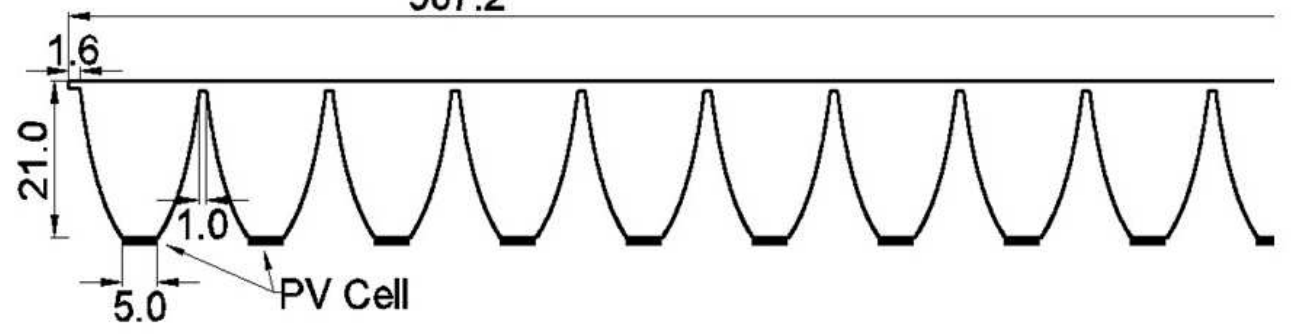

Fig. 1. 3D view and section view (part) of dielectric CPC panel (unit: $\mathrm{mm}$ )

The basic design of the PV/T/D system with dielectric CPC panel is illustrated in Fig. 2: a transparent acrylic sheet with many circular perforations is attached with some distance to the base of dielectric CPC panel to form the plenum for this system. An exhaust fan is installed in the air outlet to provide required suction during operation. The concentrated heat on the PV cells at the base of dielectric CPC panel is partially transferred to the plenum air that could be exhausted and used for thermal application. At the same time, the temperature of PV cells could be reduced to improve its efficiency; and most importantly, the heat flow from the dielectric CPC panel to atrium space could be reduced. The dimensions of this PV/T/D system are listed in Table 1 in detail. The pitch distance of the perforation plate is the closest distance between the adjacent perforations. Similar to the dielectric CPC panel, the perforation panel and side walls are also made of acrylic with high light transmittance to guarantee the daylight transmission. 


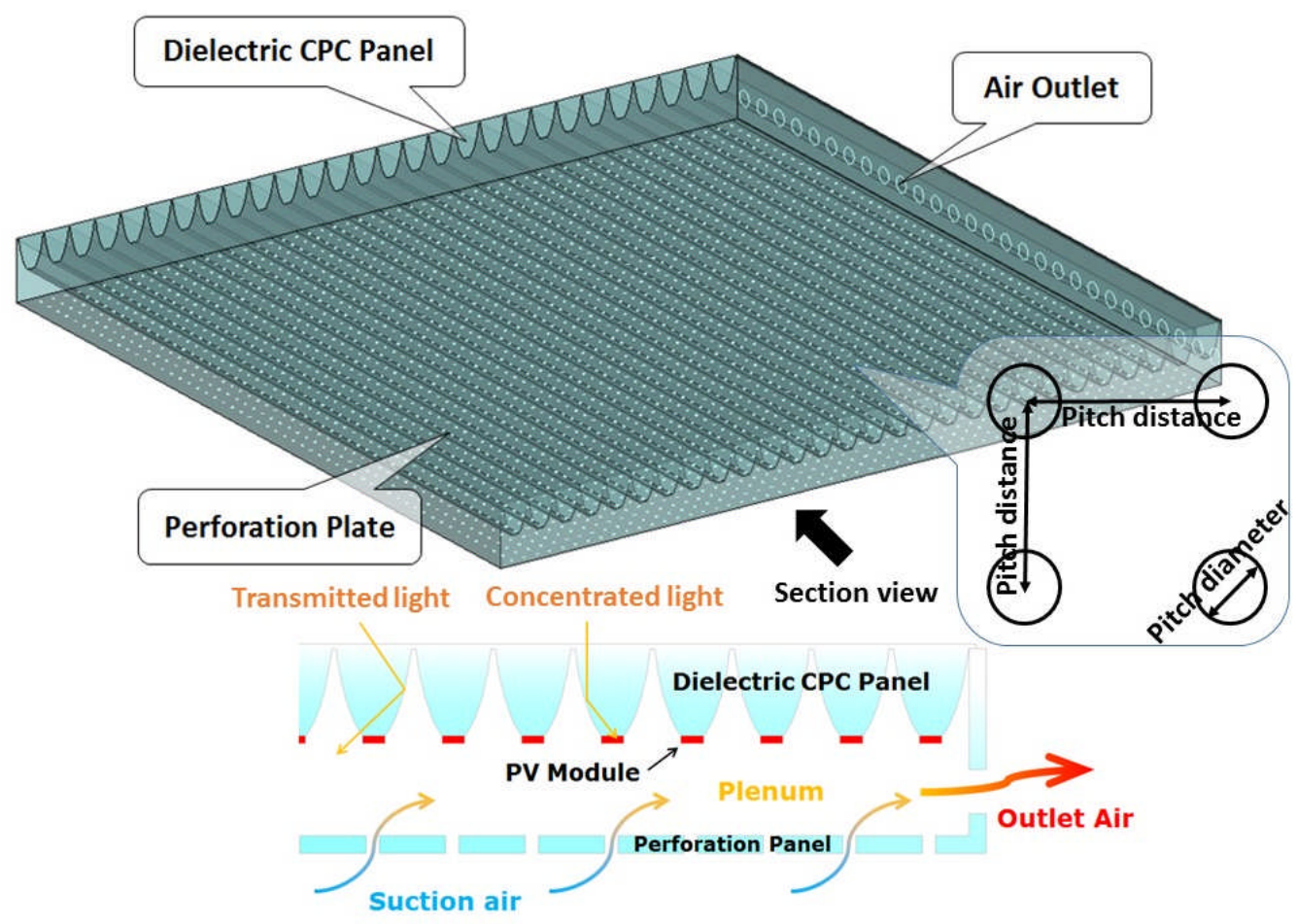

Fig. 2. Schematic diagram of the perspective and sectional view of PV/T/D system

Table 1. Dimensions of dielectric PV/T/D system

\begin{tabular}{|l|l|}
\hline Dimensions of CPC panel & Dimension \\
\hline Width of CPC panel (including 1.6mm*2 overhangs) & $507.2 \mathrm{~mm}$ \\
\hline Length of CPC panel & $500 \mathrm{~mm}$ \\
\hline Height of CPC panel & $21 \mathrm{~mm}$ \\
\hline Number of mini dielectric CPC rods in the panel & 28 \\
\hline $\begin{array}{l}\text { Dimension of each dielectric CPC rod: } \\
\text { Front aperture width; } \\
\text { Base aperture (PV) width; }\end{array}$ & $18 \mathrm{~mm}$ \\
\hline $\begin{array}{l}\text { Length; } \\
\text { Conjunction gap between CPC rods }\end{array}$ & $5 \mathrm{~mm}$ \\
\hline Width of PV cell under each dielectric CPC rod & $500 \mathrm{~mm}$ \\
\hline Geometrical concentration ratio & $1 \mathrm{~mm}$ \\
\hline Refractive index of acrylic & $5 \mathrm{~mm}$ \\
\hline Inner half acceptance angle & 3.6 \\
\hline Dimensions of transpired solar collector & 1.49 \\
\hline Width and length of air plenum & $14.48^{\circ}$ \\
\hline Height of air plenum & \\
\hline Pitch dimension of perforation plate & $500 \mathrm{~mm}^{*} 504 \mathrm{~mm}$ \\
\hline Pitch diameter of perforation plate & $30-60 \mathrm{~mm}^{+}$ \\
\hline Thickness of perforation plate and side walls & $4.5-18 \mathrm{~mm}^{+}$ \\
\hline Number of Air outlet & $0.75-3 \mathrm{~mm}^{+}$ \\
\hline Diameter of air outlet & $6 \mathrm{~mm}^{\circ}$ \\
\hline these value are due to be determined during parametric study. \\
\hline the & 28 \\
\hline
\end{tabular}




\subsection{Computational modelling}

\subsubsection{Geometry model and boundary conditions}

Due to the limitation of computer process speed and capability, and to ensure the quality of mesh and accuracy of the results, a reduced system domain was sketched with symmetry boundary conditions to reflect the thermal and flow characteristics of the whole system. The reduced system domain built in ANSYS DesignModeler is shown in Fig. 3. The domain of numerical simulation has three regions. Region 1 is the solid region for dielectric CPC panel, whose upper surfaces are exposed to the ambient air; Region 2 and 3 are the fluid regions for plenum air and atrium air respectively, and these two regions are separated by the perforation plate. The materials used in each region and their thermophysical properties are listed in Table 2. The Meshing component contained in the ANSYS Workbench Package was used to generate the mesh. The automatic meshing method (combines Tetrahedrons \& Sweep based on complexity of the geometry) is applied to split the geometry into a number of cells. For the sizing control, the function of Curvature and Proximity was used as the geometry contained both curved and narrow surface. A large number of cells are required to be placed within the slots where the temperature and velocity gradients are expected to be significant (Badache et al., 2013). The minimum cell size was determined by the perforation diameter in each case.

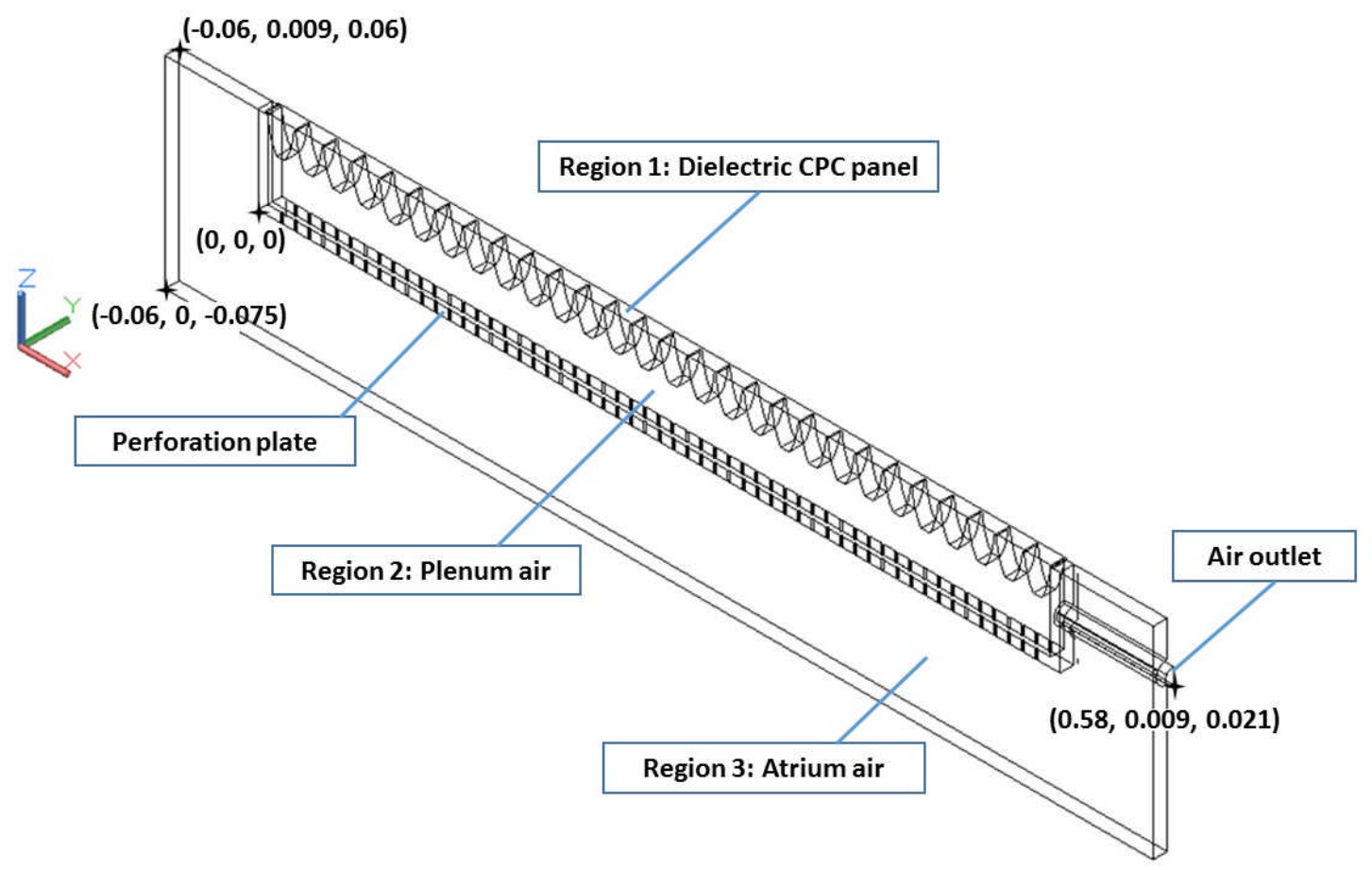

Fig. 3. Simplified system domain of PV/T/D system in the ANSYS DesignModeler

Table 2. Properties of materials used in each region

\begin{tabular}{|l|l|l|}
\hline & Region 1 & Region 2 and 3 \\
\hline Material & Acrylic glass & Air \\
\hline Density $\left(\mathrm{kg} / \mathrm{m}^{3}\right)$ & 1180 & $1.225($ Boussinesq) \\
\hline Thermal conductivity $(\mathrm{W} / \mathrm{m} \cdot \mathrm{K})$ & 0.2 & 0.0242 \\
\hline Specific heat $(\mathrm{J} / \mathrm{kg} \cdot \mathrm{K})$ & 1470 & 1006.43 \\
\hline Viscosity $(\mathrm{kg} / \mathrm{m} \cdot \mathrm{s})$ & $/$ & $1.79 \times 10^{-5}$ \\
\hline
\end{tabular}


178 Referring to Fig. 3, the boundary conditions for numerical simulation are presented as follows:

- At the plane $z=-0.075$, a pressure inlet boundary was set to allow for the entrainment of air at a temperature of $300 \mathrm{~K}$. The gauge pressure is set to be $30 \mathrm{~Pa}$ to ensure a homogeneous flow and temperature distribution over the perforation plate. Cao et al. (Cao $S$ et al., 1993) found that a distance $x_{\infty}=2 L$ was large enough to ensure that the effectiveness was independent of $x_{\infty}$, where $L$ is the pitch distance. In this case, the $L$ is 9 $18 \mathrm{~mm}$ and the distance $x_{\infty}$ of $75 \mathrm{~mm}$ is large enough so that the boundary would not interfere with the numerical solution.

- Plane $x=0.58$ is set as the velocity outlet with the velocity being set to match the desired approach velocity, and the direction is set to be parallel to $x$ direction.

- Plane $y=0$ and $y=0.009$ are specified as symmetry.

- The heat source (PV cells) was specified on the base of dielectric CPC panel, which was assumed that the solar radiation is at the rate of $600-1000 \mathrm{~W} / \mathrm{m}^{2}$; and the dielectric CPC had the concentration ratio of 3.6 and the optical efficiency of $80 \%$. Thus the heat rate on the PV module is $1728-2880 \mathrm{~W} / \mathrm{m}^{2}$. As the base of dielectric CPC panel is recognised as the interface between solid and fluid, the thermal setting for this boundary was set as coupled walls with the thickness of $0.001 \mathrm{~m}$ and the heat generation rate of $1,728,000$ $2,880,000 \mathrm{~W} / \mathrm{m}^{3}$.

\subsubsection{Energy balance equations}

The heat flow mechanism in this system is shown in Fig. 4. The heat transfer by radiation was not considered as it is negligible compared with convective heat transfer in the system. In order to simplify the modelling process, the PV cells attaching to the base of dielectric CPC are treated as the heat source. The heat generated by PV cells is transferred by conduction through the dielectric CPC and by convection to plenum air. The heat transfer occurring at dielectric CPC panel involves the convection from CPC to the ambient air through its top wall and the convection from CPC to the plenum air through the side walls of CPC rods. Heat is transferred from the plenum air to the perforation plate by convection. Finally there is convective heat transfer from perforation plate to atrium air and the air in perforation holes.

The steady-state conservation of mass equation, momentum equation, and energy equation are used as governing equations in the numerical simulation. As to the solution methodology, the governing equations were solved numerically by the widely used FLUENT software. The convergence criteria were set to be $10^{-5}$ for the mass and momentum equations, and $10^{-6}$ for the energy equation. The required output could be obtained directly from the results using the FLUENT post processing software. 


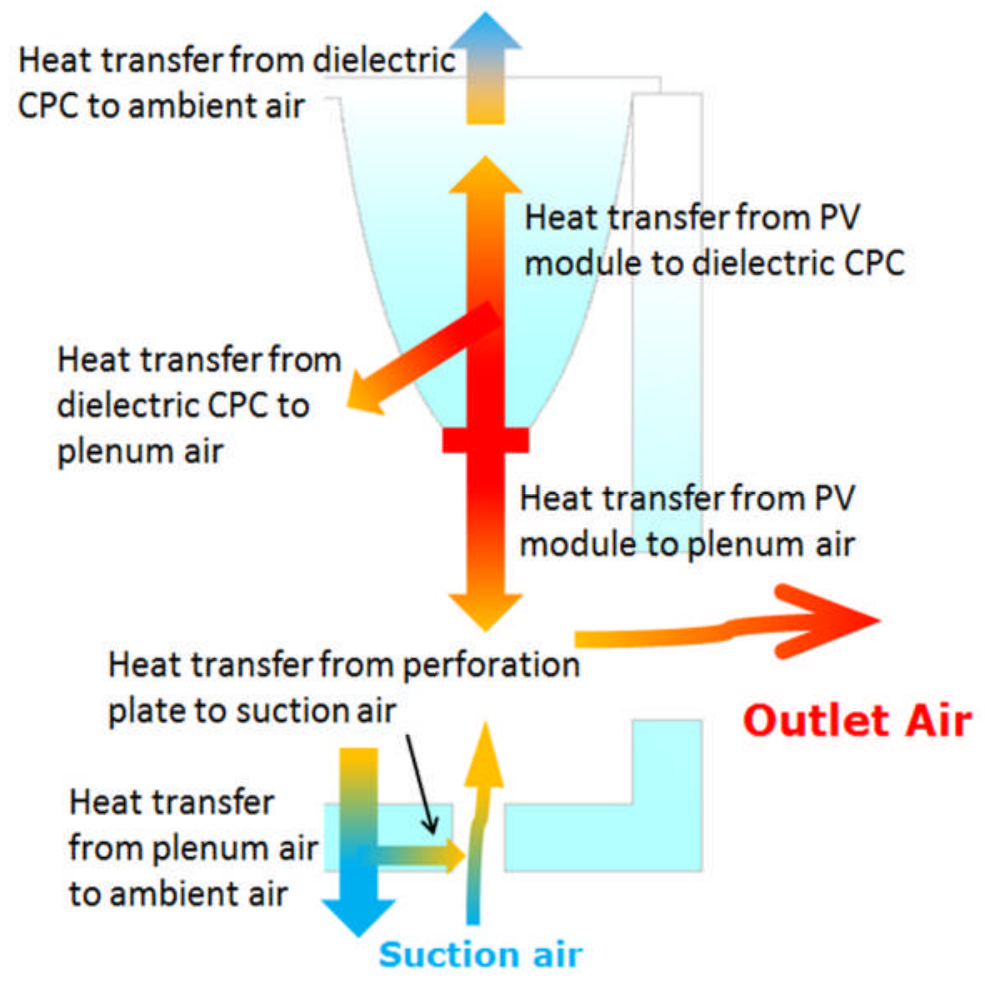

Fig. 4. Heat transfer in the system

\subsubsection{Assumptions}

215 A number of assumptions were made in formulating this model as follows:

- Flow model:

Previous numerical studies on the perforation plate suggested that given sufficient suction, turbulent transition would not occur and laminar flow assumption is sufficient to model the flow appropriately (Collins and Abulkhair, 2014). However, this assumption was not suitable for modelling air flow around the perforation plate, for the present model, the air motion in the plenum and atrium might show rather complex behaviour involving both laminar and turbulence (Badache et al., 2013). It is not possible to apply both laminar and turbulence models in a single computational domain. Therefore, the Re-Normalization Group (RNG) $k-\varepsilon$ turbulence model, which is quite frequently used for indoor air simulation involving both laminar and turbulence conditions, was applied in this model (Fuliotto et al., 2010).

- $\quad$ Fluid properties:

Since the temperature differences experienced in the system are relatively large, the Boussinesq approximation was used to account for the density variation, other thermophysical properties of the fluid are kept constant (Badache et al., 2013).

- Air flow through the perforation plate:

A pressure drop of 30Pa between Region 2 and 3 had been set to ensure a homogeneous flow and temperature distribution over the perforation plate. Minimised reversal flow through the perforation plate could be guaranteed under this pressure drop (Leon and Kumar, 2007). 


\subsubsection{Parameters input and output}

Earlier studies on UTC have shown that the key parameters influencing the efficiency of UTC collector include perforation diameter, approach velocity, solar radiation, wind speed and so forth (Leon and Kumar, 2007). Since the working principle of current dielectric CPC air heater is similar to UTC, the input variants selected for investigation include: a) Plenum height; b) approach velocity (suction velocity); c) solar radiation; d) porosity; e) pitch distance and perforation diameter. It is important to mention that the key parameters influencing the efficiency of UTC collector is the approach velocity, which normally varies from $0.01-0.05 \mathrm{~m} / \mathrm{s}$ (Leon and Kumar, 2007). A parametric study was conducted to evaluate the influences of above parameters on the thermal performance of dielectric CPC air heater. Table 3 summarized the input parameters and the ranges of values used in this study.

Table 3. Parameter input of PV/T/D system in CFD

\begin{tabular}{|l|l|}
\hline Input parameter & Range \\
\hline Plenum height & $10-30 \mathrm{~mm}$ \\
\hline Approach velocity & $0.01-0.05 \mathrm{~m} / \mathrm{s}$ \\
\hline Solar radiation & $600-1000 \mathrm{~W} / \mathrm{m}^{2}$ \\
\hline Porosity & $0.5 \%-2 \%$ \\
\hline Pitch (rectangular) & $4.5 \mathrm{~mm}-18 \mathrm{~mm}$ \\
\hline Perforation diameter & $0.75 \mathrm{~mm}-3 \mathrm{~mm}$ \\
\hline Pressure drop across the perforation plate & $30 \mathrm{~Pa}$ \\
\hline Ambient and atrium temperature & $300 \mathrm{~K}$ \\
\hline
\end{tabular}

The output parameters include: a) air temperature rise; b) heat recovery efficiency; c) PV surface temperature; d) distribution of heat flux. The heat recovery efficiency is used to evaluate the thermal performance of this system, which is defined as the ratio of heat removal or recovery delivered air flow to the absorber solar radiation by PV cells on the base of dielectric CPC. Therefore:

$$
\eta_{\text {air, heater }}=\dot{m}_{\text {air, out }} * c_{p, \text { air }}\left(T_{\text {out }}-T_{\text {atrium }}\right) / A_{P V} I_{P V}
$$

where $\eta_{\text {air, heater }}$ is the thermal efficiency of PV/T/D system; $\dot{m}_{\text {air, out }}$ is the mass flow rate of sucked air; $c_{p}$, air is the specific heat of air; $T_{\text {atrium }}$ is the temperature of air in atrium; $T_{\text {out }}$ is the temperature of outlet air; $A_{P V}$ is the area of PV cells attached on the base of dielectric CPC panel; $I_{P V}$ is the absorbed solar radiation on the PV cells;

\subsection{Experiment under simulated sky}

The prototype of PV/T/D system was tested on the photometric integrator, which is a convenient method to measure light transmission ratio. It is regulated by British standard BS EN 13032-1:2004+A1:2012 (BSI, 2005). It has been widely applied to assess the performances of optical equipment and luminaires by Building Research Establishment Ltd. (BRE) (Littlefair and Graves, 2008, Littlefair and Ticleanu, 2012, Howlett, 2015). The integrator was a wooden cubic chamber. The vertical layout of the system is schematically sketched in Fig. 5 . The system used in experiment has same structure and dimensions introduced in Table 1 and Fig. 2. One 
of the typical dimensions of perforation plate was chosen in test. The perforation plate in test was made of $6 \mathrm{~mm}$ thick transparent acrylic sheet, on which $3080\left(55^{*} 56\right)$ slots were equally distributed, and the slots were manufactured by laser cutting with an accuracy of $\pm 0.1 \mathrm{~mm}$. It had the pitch of $9 \mathrm{~mm}$ and the perforation diameter of $1.5 \mathrm{~mm}$. The porosity of it was $2.16 \%$. Both indoor and outdoor experiments were taken in this study.

The indoor experimental rigs include three parts: a) a solar simulator providing constant parallel solar radiation (not shown in the sketch) (the uniformity of the solar radiation over the plate is within $\pm 3 \%$ ); $b$ ) an extraction fan drawing the air through the PV/T/D system at a certain flow rate; $c$ ) some meters including one pyranometer ( $\pm 2 \%$ in uncertainty) to measure the solar radiation; one anemometer (accuracy of $\pm 3 \%$ and $\pm 0.15 \mathrm{~m} / \mathrm{s}$ ) to measure the air velocity at outlet; several K-type thermocouples $\left( \pm 1.5^{\circ} \mathrm{C}\right.$ in accuracy) which are connected to the automatic data acquisition system; $d$ ) a PV/T/D prototype which consists of dielectric CPC panel, transparent perforation plate and air gap (plenum). The outdoor experiment was taken on a sunny day in Nottingham, UK $\left(53^{\circ} \mathrm{N}, 1.2^{\circ} \mathrm{W}\right)$ by the same experimental rig. The experimental integrator was tilted in a certain angle such that the dielectric CPC panel could directly face the sunlight. Fig. 6 shows the photos of indoor and outdoor experiments.

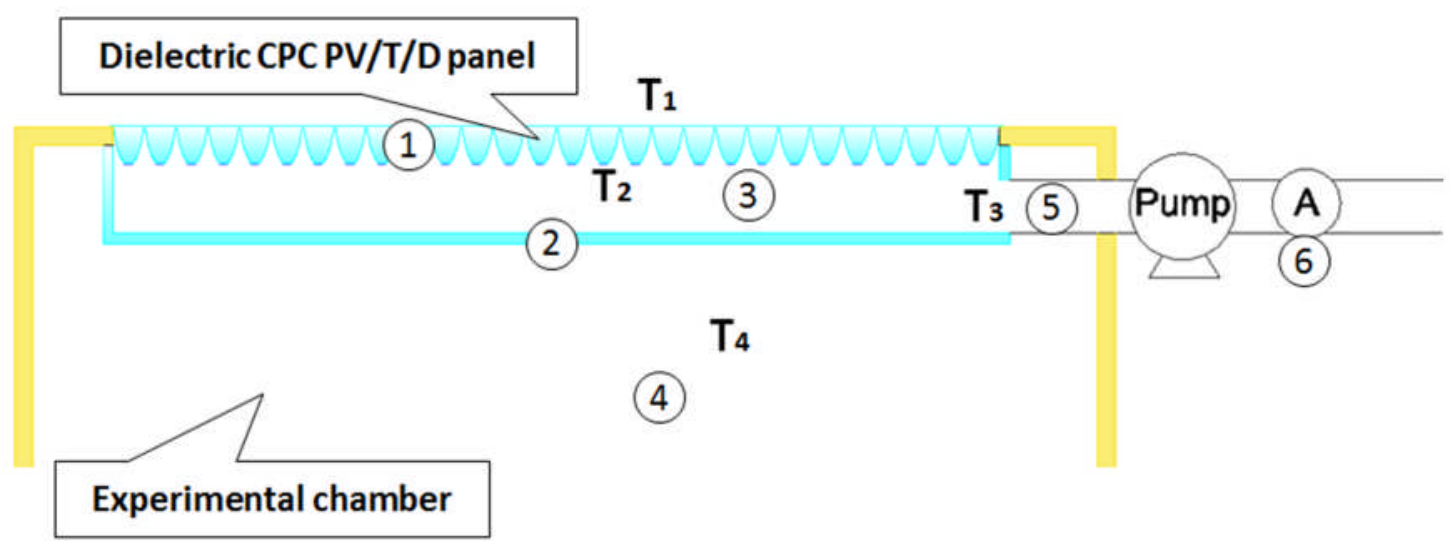

Fig. 5. Vertical layout of the experimental set-up: 1) dielectric CPC panel; 2) perforation plate; 3) plenum; 4) chamber interior; 5) air outlet; 6) anemometer.
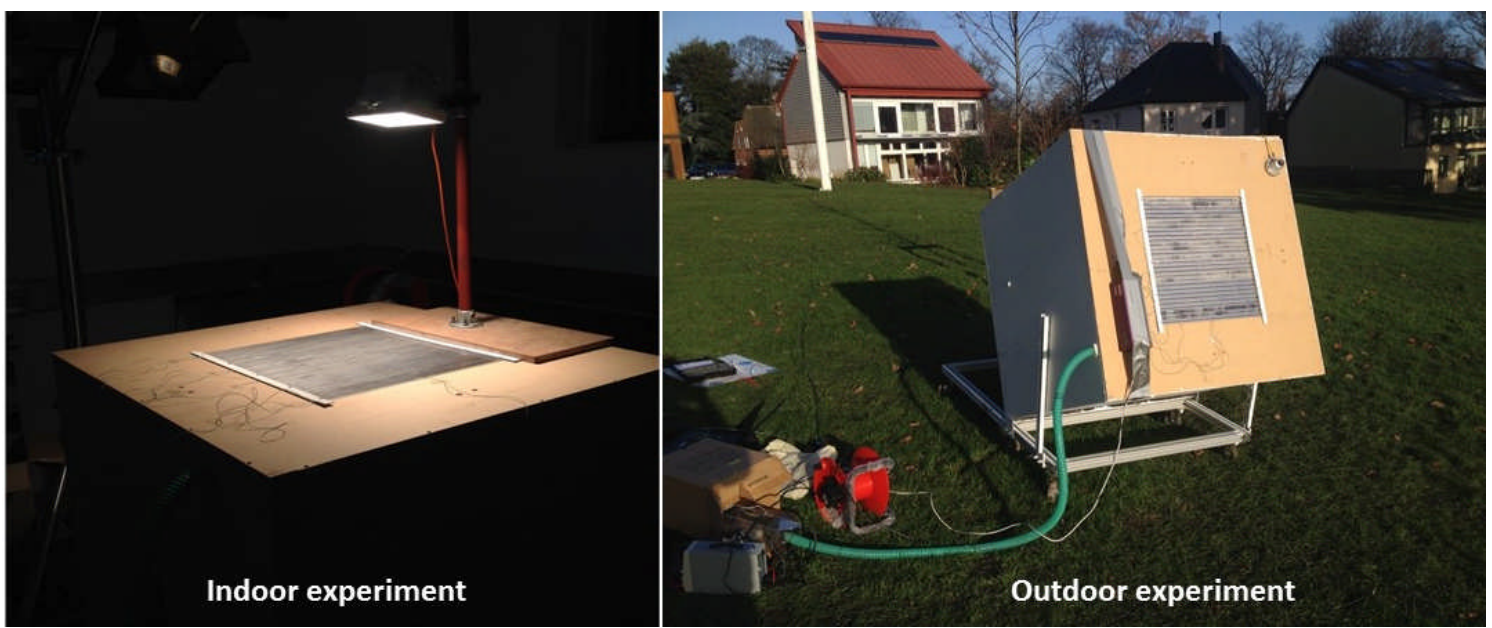

Fig. 6. Experimental rig for indoor and outdoor testing 
The experiment was designed to measure the delivered air temperature, PV surface temperature, the heat recovery efficiency under certain solar radiation $\left(\mathrm{I}_{\mathrm{r}}\right)$ and given air flow rate $(\dot{m})$. The thermocouples were arranged as follows: one thermocouple was attached to the dielectric CPC panel surface to measure its surface temperature $\left(T_{1}\right)$; one thermocouple $\left(T_{2}\right)$ was attached to the back of one PV cell to measure its temperature; the delivered air temperature was measured by thermocouple $T_{3}$ which is located at air outlet; and the chamber air temperature was measured by thermocouple $\mathrm{T}_{4}$. Therefore, the heat recovery efficiency from experiment $\eta_{\text {experiment }}$ could be calculated as follows:

$$
\eta_{\text {experiment }}=\dot{m} * c_{p, \text { air }}\left(T_{3}-T_{4}\right) / A_{P V} I_{P V}
$$

Where $\dot{m}$ is the mass flow rate of sucked air; $c_{p}$, air is the specific heat of air; $A_{P V}$ is the area of PV cells, which is $0.005 \mathrm{~m}^{*} 0.5 \mathrm{~m} * 28$ in the current case; $I_{P V}$ is the incident solar radiation on the PV cells, which could be measured through the measurement of the short circuit current of the PV cells with and without the CPC, and in this case, the measured effective concentration ratio was 1.8 so that $I_{P V}$ is 1.8 times of the solar radiation level on the dielectric CPC surface.

During the experiment, the air was drawn from the interior experimental chamber by circular pipe line which is connected to the extraction fan. The speed of the fan (air flow rate) was controlled by its voltage input.

\section{Results and discussion}

\subsection{CFD simulations}

\subsubsection{Flow characteristics}

An example of the temperature distributions and flow characteristics in the modelled regions are illustrated in Fig. 7. The constant inputs parameters of Fig. 7 are as follows: plenum height: $10 \mathrm{~mm}$; perforation diameter: $1.5 \mathrm{~mm}$; pitch distance: $9 \mathrm{~mm}$; perforation porosity: $2 \%$; solar radiation: $1000 \mathrm{~W} / \mathrm{m}^{2}$; approach velocity: $0.01 \mathrm{~m} / \mathrm{s}$. The parametric studies will be presented in the following sections. The criteria investigated in parametric studies are approach velocity, plenum height, pitch and perforation diameter, porosity, and solar radiation.

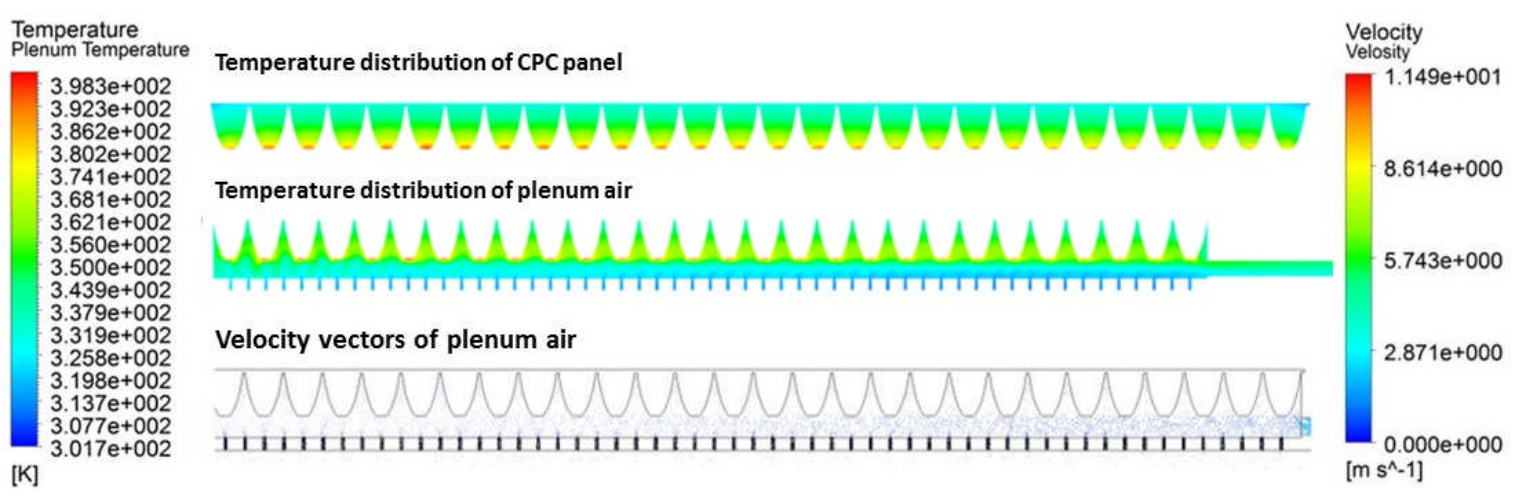

Fig. 7. Example of flow characteristics in PV/T/D system by CFD 


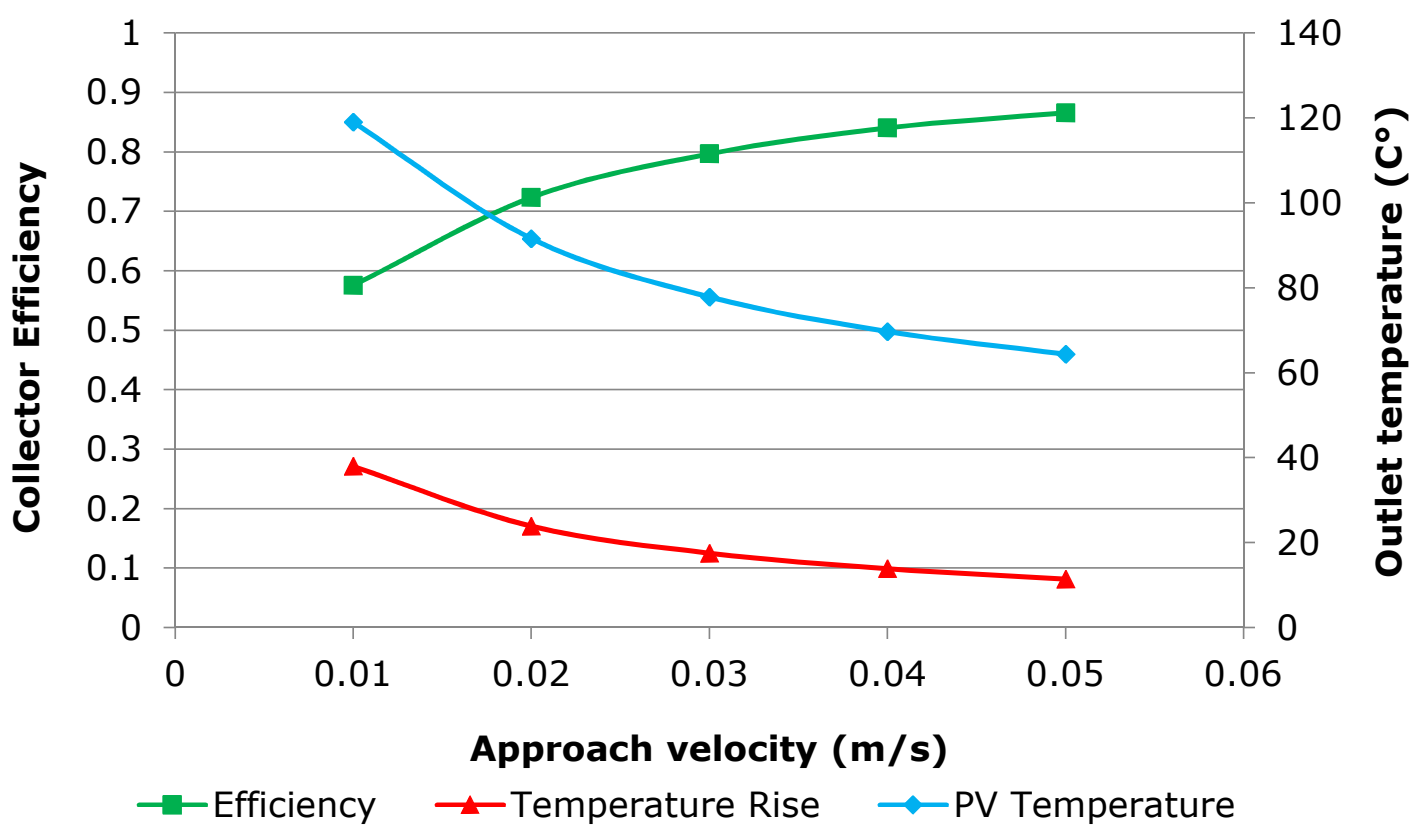

Fig. 8. Effects of approach velocity on the temperature of PV cell, outlet temperature rise and thermal efficiency of the system

Fig. 8 represents the influence of approach velocity on the thermal collector efficiency, outlet temperature rise and $\mathrm{PV}$ operating temperature under fixed solar radiation, perforation and plenum dimension. The outlet air temperature rises and $\mathrm{PV}$ temperature decreases with rising approach velocities. The opposite trend is found for the thermal collector efficiency. Given the solar radiation of $1000 \mathrm{~W} / \mathrm{m}^{2}$, perforation diameter of $1.5 \mathrm{~mm}$, pitch distance of $9 \mathrm{~mm}$ and plenum height of $10 \mathrm{~mm}$, the heat recovery efficiency increases rapidly when the approach velocity changes from $0.01 \mathrm{~m} / \mathrm{s}$ to $0.03 \mathrm{~m} / \mathrm{s}$, and tends to be nearly constant after $0.03 \mathrm{~m} / \mathrm{s}$. The results are generally consistent with earlier study of UTC collector by Kutscher et al (Kutscher et al., 1993). The thermal efficiency of collector could be as high as above $80 \%$ for the designed $\mathrm{PV} / \mathrm{T} / \mathrm{D}$ system. It seems that the higher approach velocity is preferred to obtain higher thermal efficiency and lower PV operating temperature; however, more power input for suction blower is required to meet the target approach velocity. A comprehensive trade-off for the velocity determination is required.

The concentrated heat on the PV cells would be transferred to three destinations, which are ambient air through the upper surface of dielectric CPC panel, plenum air then to air outlet, and atrium air through the perforation plate. Fig. 9 further illustrated the proportion of heat transfer in each destination. It could be found that the heat flux to the plenum air dominate among three heat transfers. Additionally, its percentage increases with the rising approach velocity. As the air flow rate is proportional to the approach velocity, increasing in approach velocity means linear increasing of the air flow rate in plenum. The effect of convection heat transfer to the plenum would be enhanced due to the increased air flow rate, and consequently the heat flux to the ambient air and atrium air would be reduced. However, there seems to be no obvious reduction in heat flux to atrium air with the changing approach velocity. to the plenum by suction air due to the suction effect of the perforation plate. Thus the actual 
heat flux to the atrium should subtract the heat that is taken back to the plenum. According to the previous researches, for perforation plate, if a minimum pressure drop of $25 \mathrm{~Pa}$ and a minimum approach velocity of $0.02 \mathrm{~m} / \mathrm{s}$ are provided, the convective heat loss could be neglected since the convective boundary layer is continuously sucked off (Kutscher, 1994). It can be found that almost all the heat flow through the perforation plate could be drawn back to the plenum and the amount of heat flow down to the atrium space could be small and neglected, which achieve the first design objective of the PV/T/D system, i.e., minimising solar heat gain.

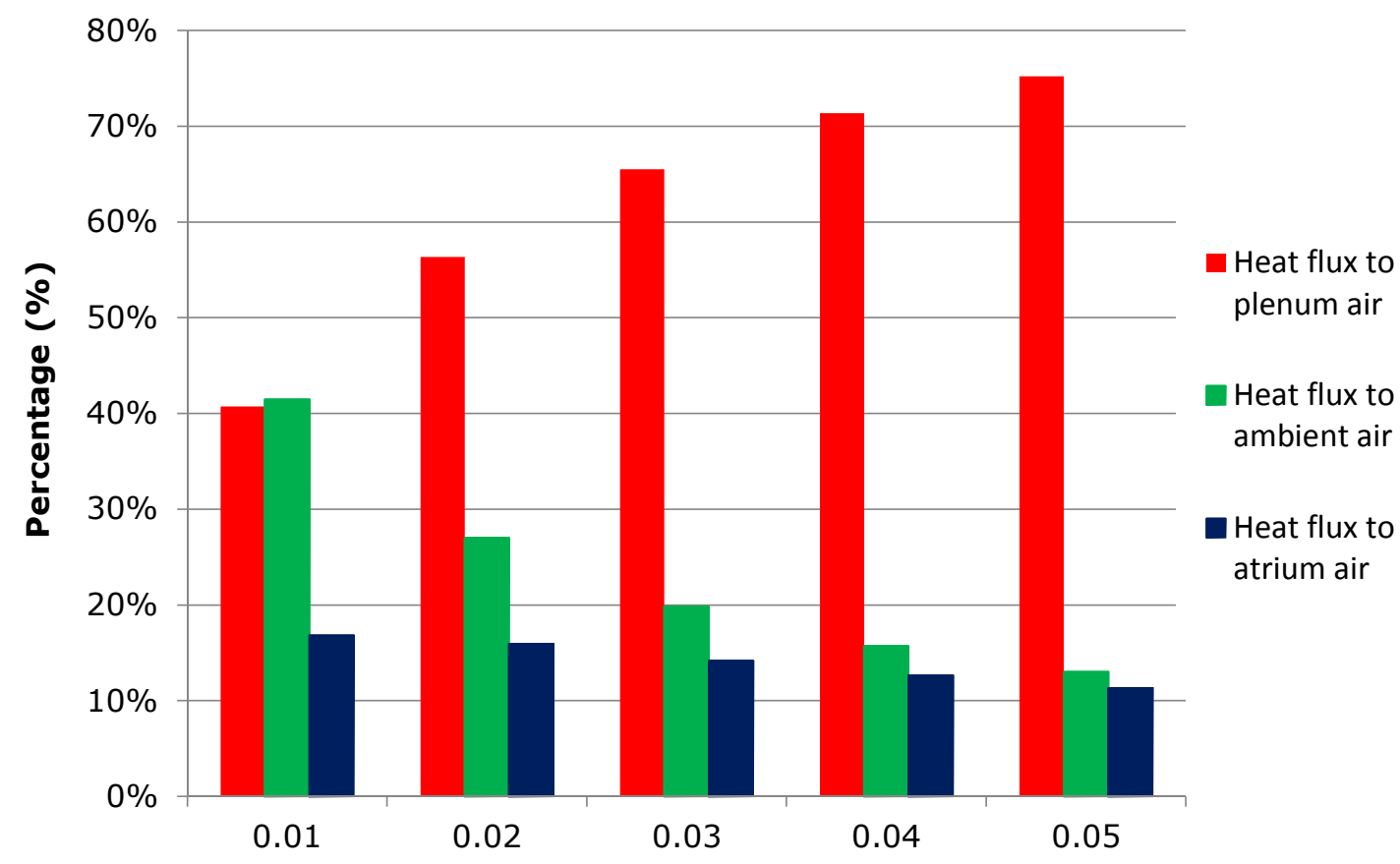

Approach Velocity $(\mathrm{m} / \mathrm{s})$

Fig. 9. Proportion of heat transfer to each destination

\subsubsection{Effects of plenum height}

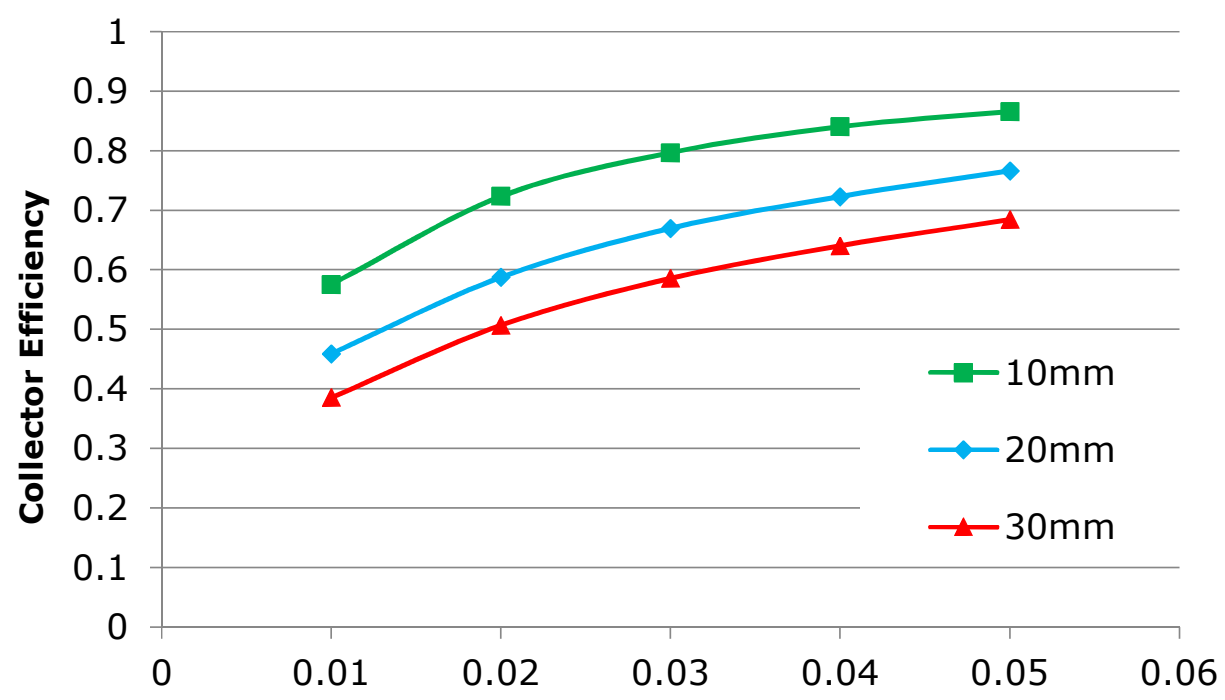

Suction Velocity $(\mathrm{m} / \mathrm{s})$ 


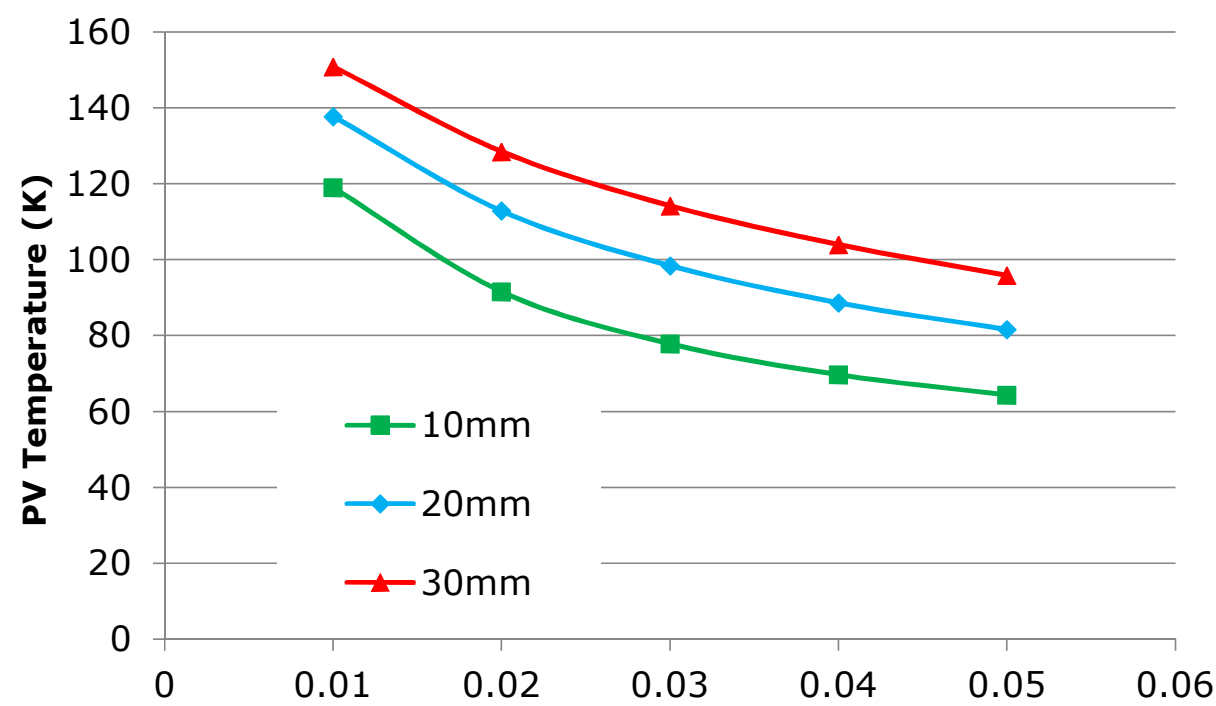

Suction Velocity $(\mathrm{m} / \mathrm{s})$

According to Figs. 10 and 11, it could be observed that the plenum height has a significant influence on the thermal efficiency and PV operating temperature. Smaller plenum height seems to be preferred as it could result in higher temperature rise and thermal collector efficiency, and lower PV operating temperature under fixed approach velocity. This phenomenon could be explained that smaller distance between the perforation plate and PV module could result in more air flowing through the bottom of PV module and enhance the convective heat transfer to the plenum air. This could be further proved by Fig. 12. Larger plenum height could cause lower proportion of convective heat transfer to the plenum air. However, the fraction pressure drop also needs to be considered when deciding the plenum height (Leon and Kumar, 2007). 


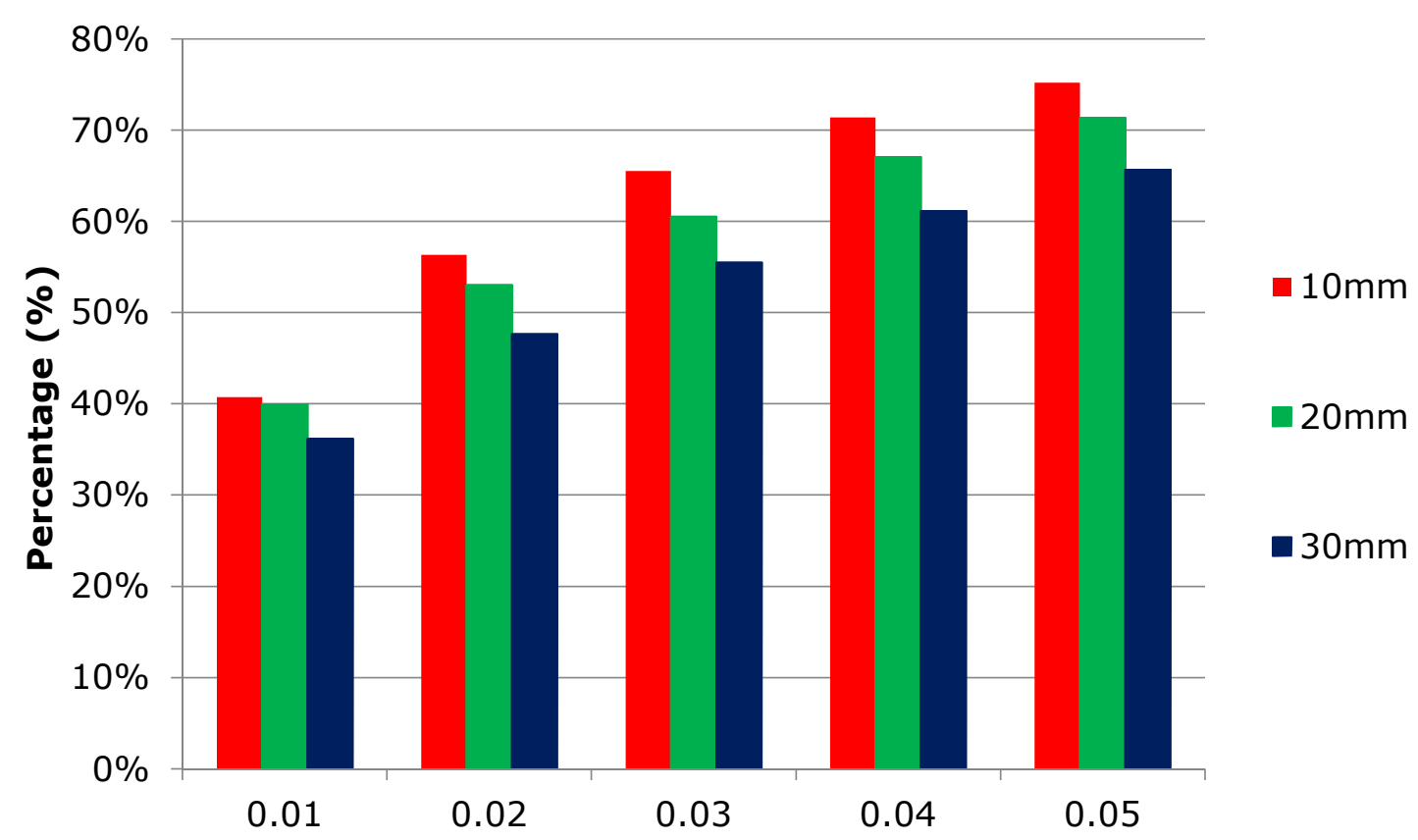

Approach Velocity $(\mathrm{m} / \mathrm{s})$

Fig. 12. Percentage of heat flux to plenum air at different plenum heights

\subsubsection{Effects of pitch and perforation diameter}

The effects of pitch and corresponding perforation diameter on the CPC-PV/T/D system performance were investigated and their results were illustrated in Figs. 13 and 14 . Under the same porosity and pitch layout, the pitch perforation diameter has slight influence on the collector performance and PV surface temperature. Changing the pitch from $9 \mathrm{~mm}$ to $18 \mathrm{~mm}$ (and a corresponding change in perforation diameter from $1.5 \mathrm{~mm}$ to $3 \mathrm{~mm}$ ) could result in only $1-3 \%$ increase of thermal collector efficiency and $5-10^{\circ} \mathrm{C}$ drop of PV surface temperature. These results are different from the findings of Leon and Kumar's research, who concluded that perforation diameter had significant effects on the thermal performance of the UTC system (Leon and Kumar, 2007). It could be explained as that the perforation plate in UTC acts as the solar absorber where the heat transfer occurred on the front surface, in the hole and on the back of the plate, any slight change in perforation plate dimension (pitch and perforation diameter) would significantly influence its performance; while for the current CPC-PV/T/D system, the PV cell at the base of dielectric CPC is regarded as heat source, as a result, changes in pitch and perforation diameter has only slight or even rare influence on the thermal performance of the system. 


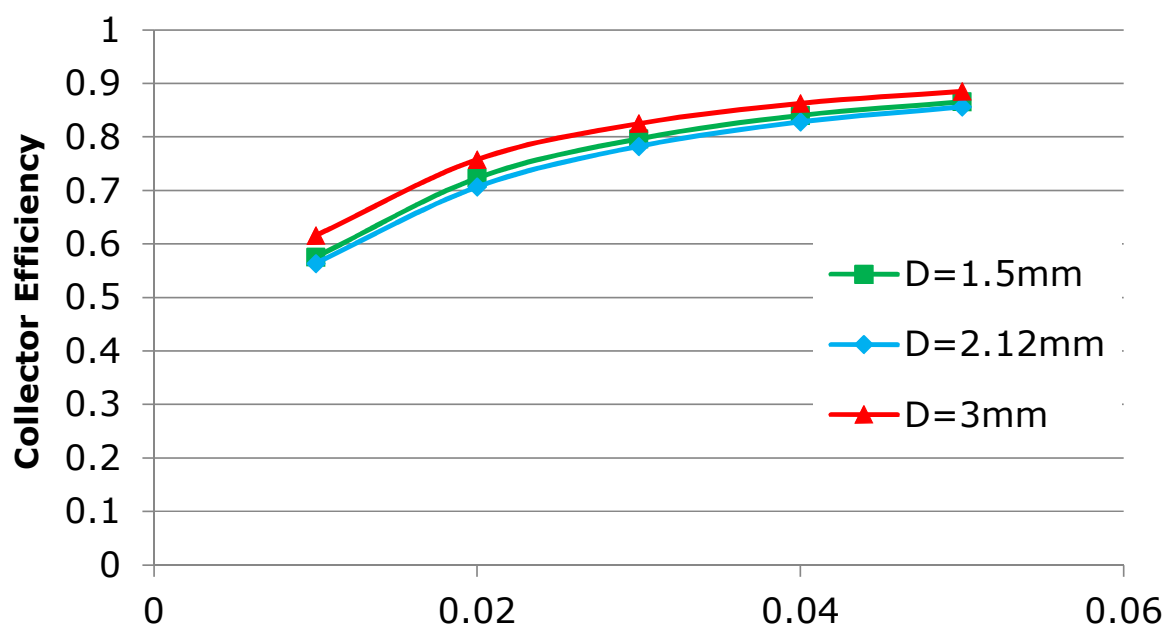

Suction Velocity $(\mathrm{m} / \mathrm{s})$

Fig. 13. Effect of pitch-perforation diameter on the collector efficiency

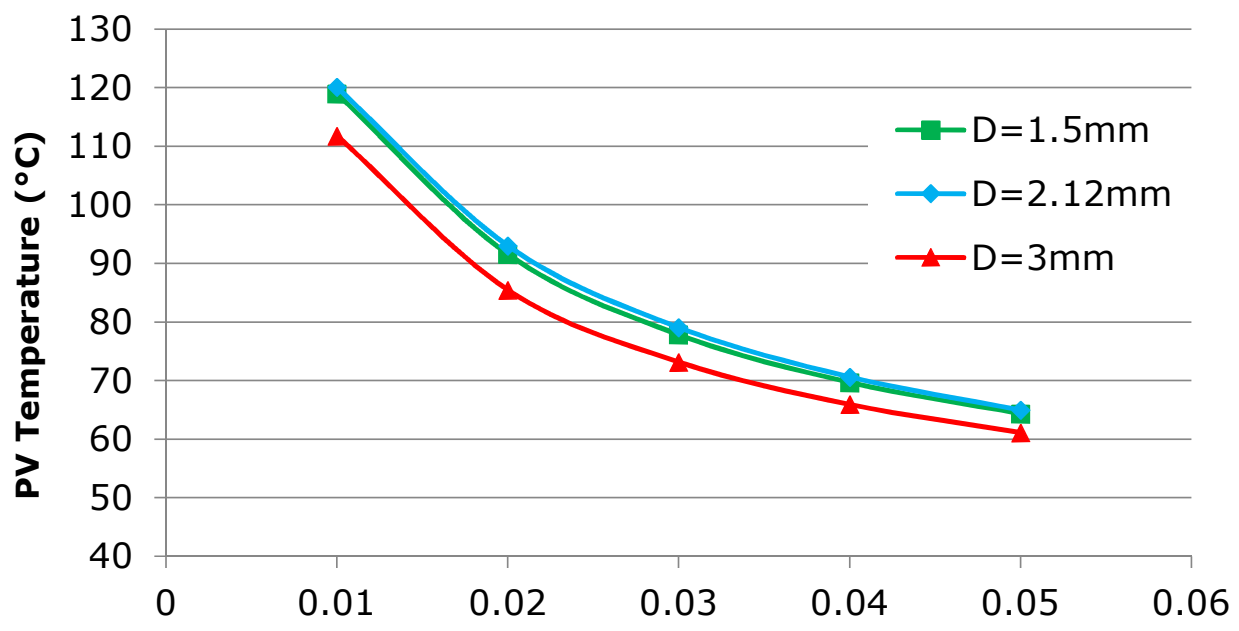

Suction Velocity $(\mathrm{m} / \mathrm{s})$

Fig. 14. Effect of pitch-perforation diameter on the PV surface temperature

\subsubsection{Effects of perforation plate porosity on efficiency and PV Temperature} Under constant perforation diameter $(1.5 \mathrm{~mm})$, the influence of perforation porosity on the thermal collector efficiency and PV operating temperature is insignificant: $150 \%$ (from $0.5 \%$ to $2 \%$ ) increase in porosity could result in only $4.20 \%-18.61 \%$ decrease in thermal collection efficiency and 14.95\%-19.15\% increase in PV operating temperature under studied approach velocities (Figs. 15 and 16). It is consistent with Leon's results on the influence of porosity on the thermal efficiency of UTC collector (Leon and Kumar, 2007). In addition, the significance of changing porosity on the thermal efficiency and PV temperature would decrease under larger approach velocity. 


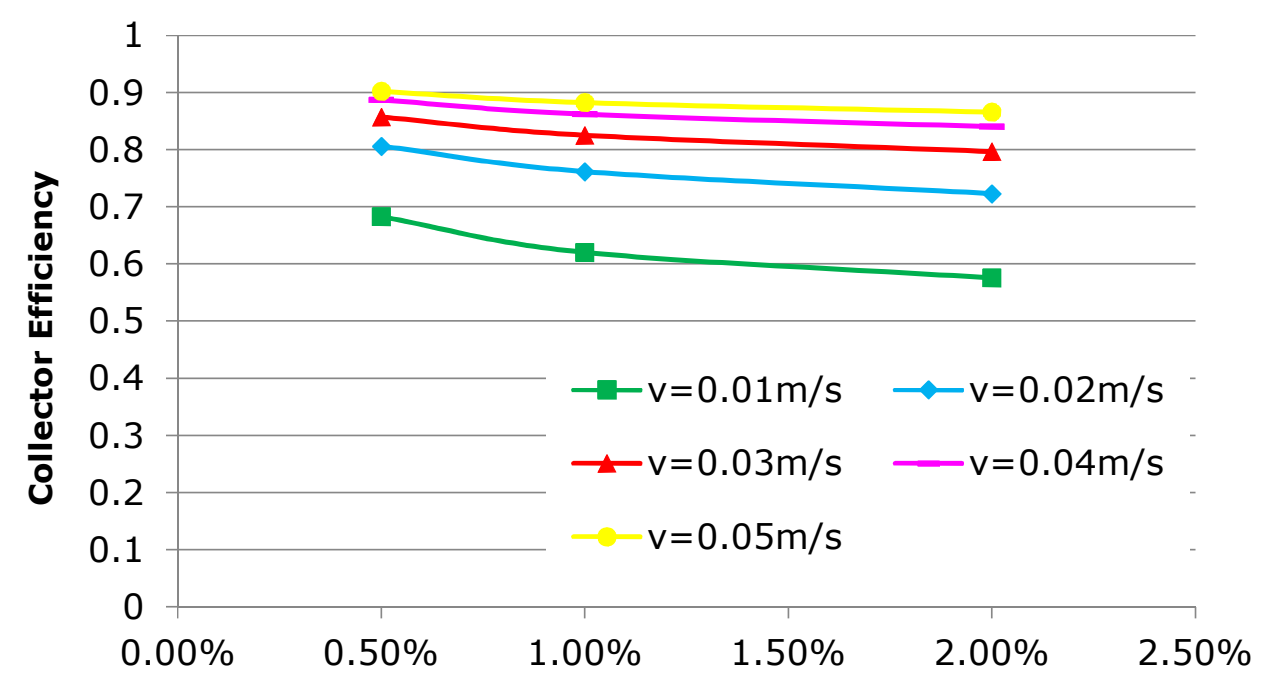

406

407

\section{Perforation Porosity (\%)}

Fig. 15. Effect of perforation porosity on collector efficiency

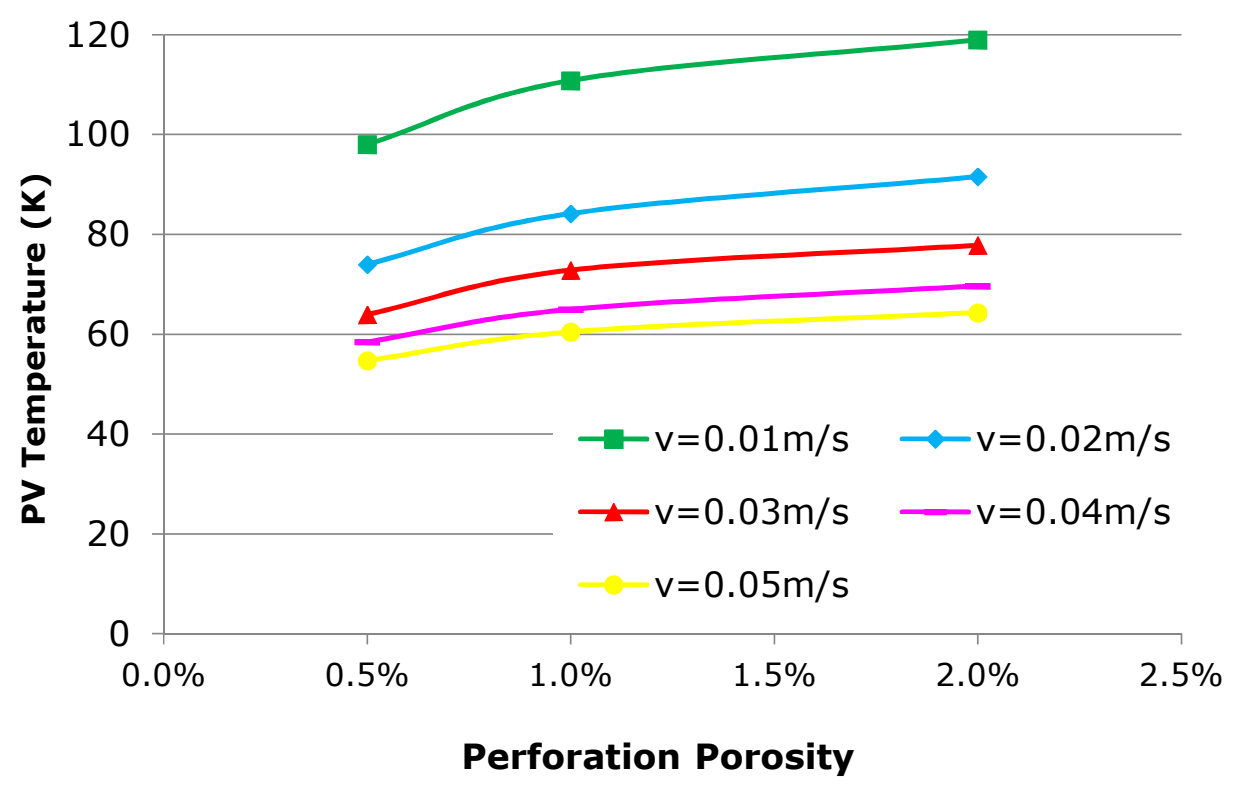

Fig. 16. Effect of perforation porosity on the PV surface temperature

\subsubsection{Effects of solar radiation}

The influences of the solar radiation on the PV temperature and collector efficiency were investigated and demonstrated in Figs. 17 and 18. PV operating temperature would dramatically decrease with the reduction of solar radiation. The amount of temperature drop depends on the approach velocities. However, the thermal collector efficiency keeps constant under different solar radiation levels as presented in Fig. 18, showing that the solar thermal collector efficiency for this PV/T/D system is independent of the solar radiation level. These results are consistent with the finding of Leon and Kumar (Leon and Kumar, 2007). 


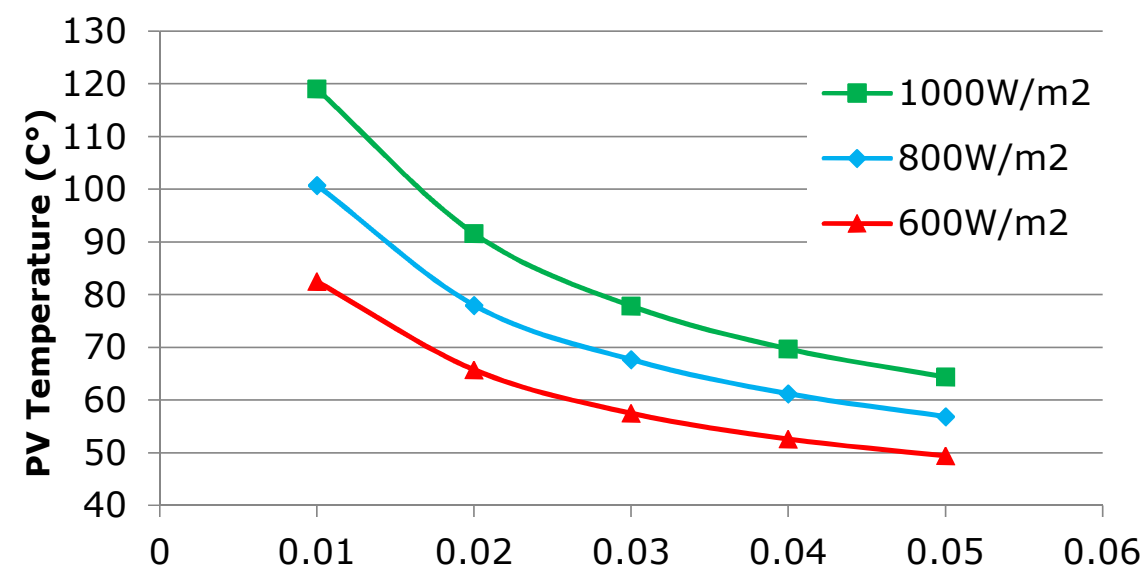

Suction Velocity $(\mathrm{m} / \mathrm{s})$

Fig. 17. Effect of solar radiation on the PV temperature

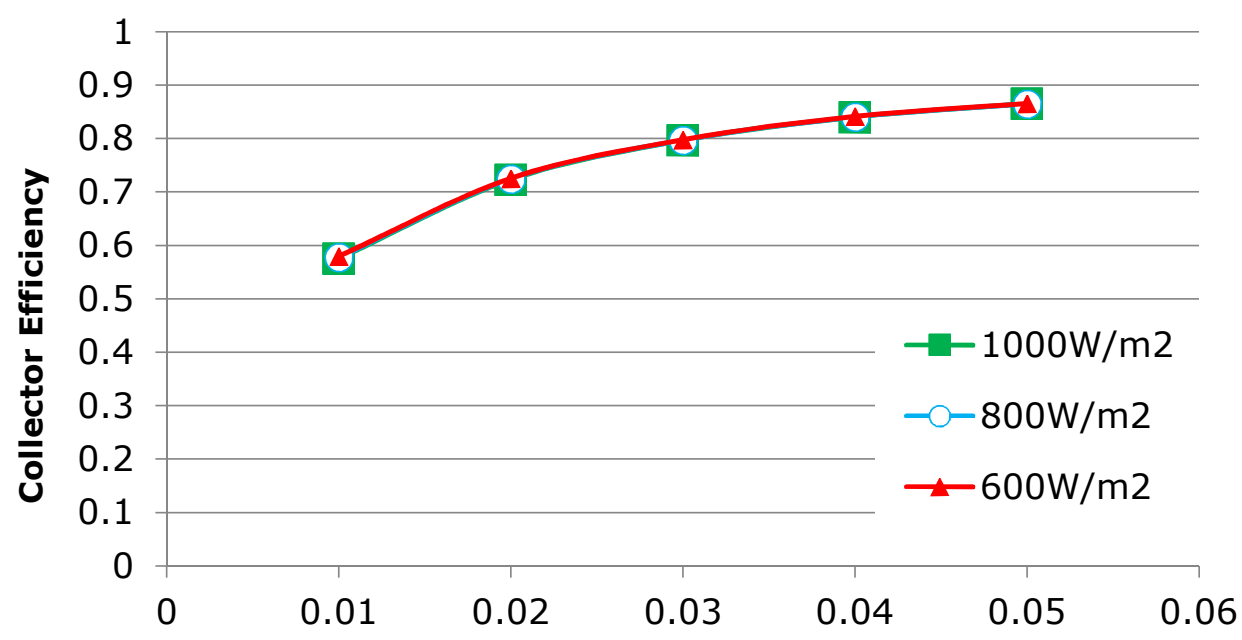

Suction Velocity $(\mathrm{m} / \mathrm{s})$

Fig. 18. Effect of solar radiation on the collector efficiency

\subsection{Experiment under solar simulator and real sky}

The preliminary indoor testing was made under constant solar radiation level of $705.85 \mathrm{~W} / \mathrm{m}^{2}$ provided by the solar simulator. Fig. 19 demonstrates the results of indoor experiment. At first, the extraction fan was turned off. The PV absorbed the solar radiation and its temperature consistently increased until the steady state temperature of about $321 \mathrm{~K}\left(47.85^{\circ} \mathrm{C}\right)$ was reached. During the same period, the air inlet and outlet temperature also increased but not as dramatically as the PV and CPC surface temperature. At about 6900 seconds, the extraction fan was turned on and adjusted to the speed at which the air volume flow rate of $0.0128 \mathrm{~m}^{3} / \mathrm{s}$ (corresponding approach velocity of $0.0512 \mathrm{~m} / \mathrm{s}$ ) was achieved, the PV temperature would dramatically decrease to $313 \mathrm{~K}$, and the air outlet temperature would increase from $291 \mathrm{~K}$ to 295K. This phenomenon showed that the proposed PV/T/D prototype has the ability to transfer the heat rejected by PV cells to the plenum air and deliver it to the air outlet; meanwhile, PV efficiency could be enhanced due to its low surface temperature. Afterwards, the fan speed was decreased twice to investigate the effects of the suction air velocity on the $\mathrm{PV} / \mathrm{T} / \mathrm{D}$ system and chamber. Clear changes in PV surface temperature could be observed in 
the results. Most importantly, it could also be observed that the air temperature in the environmental chamber (air inlet temperature) could keep constant, especially after the suction fan was turned on, which showed that little rejected heat was transferred to the environmental chamber so that the design aim of the CPC-PV/T/D system was achieved.

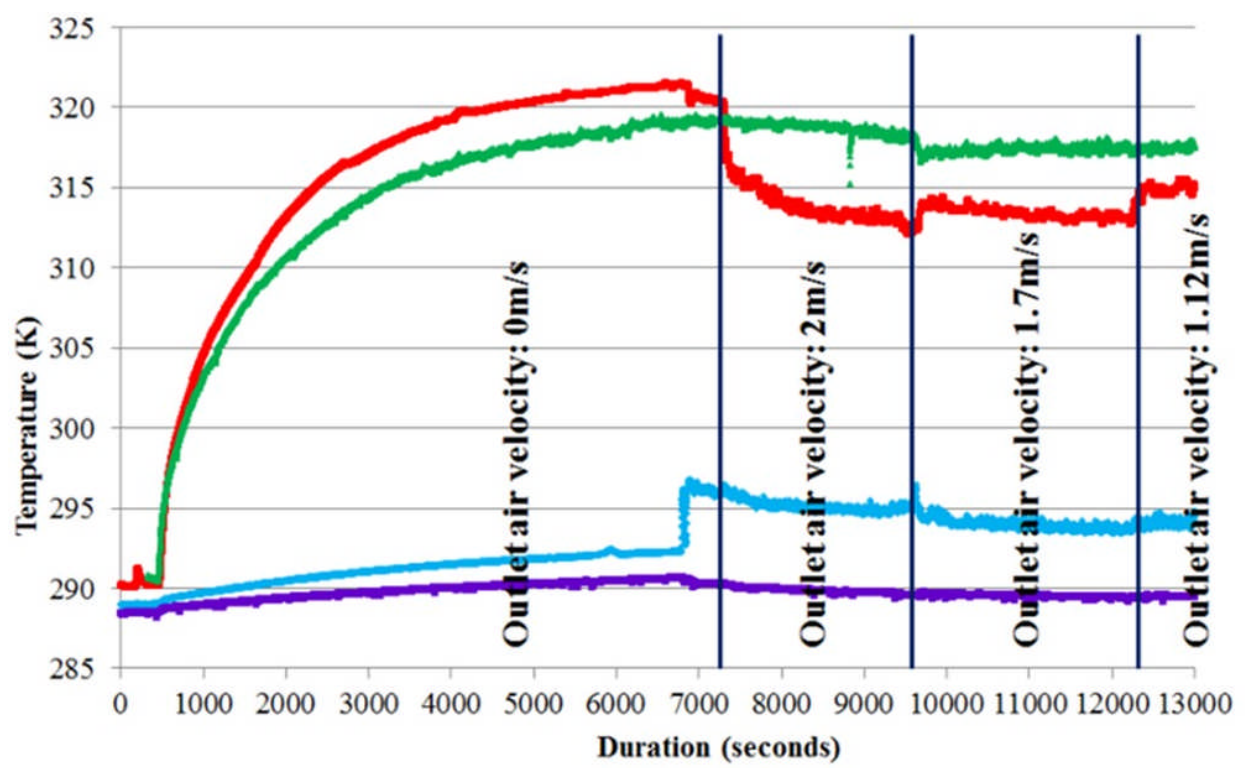

- Air outlet temperature $\bullet$ PV Temperature $\odot$ CPC surface temperature $\bullet$ Air inlet temperature

Fig. 19. Results of Indoor experiment (solar radiation: $705.85 \mathrm{~W} / \mathrm{m}^{2}$ )

The indoor test results were also used to calculate the heat recovery efficiency. In order to compare the simulation and experiment results, the ambient temperature of simulation was adjusted to $288 \mathrm{~K}$ to keep consistent with the experiment condition. The results and their comparison with the simulated results by CFD were shown in Fig. 20. It could be observed that the simulated collector efficiencies were higher than the measured ones. The deviation is relatively larger as the approach velocity is small. When the approach velocity is increased to $0.05 \mathrm{~m} / \mathrm{s}$, the two results are quite close. One main reason for the deviation may be due to the simple assumption of constant heat transfer coefficient on the top of CPC panel. However, both simulation and experiment results provide similar tendencies about the relationship between approach velocity and collector efficiency. Apart from the measuring errors in experiment, the assumptions made for material properties and the boundary condition settings in CFD simulation were also the reasons that cause the differences. The results could verify the CFD simulations to some extent. 


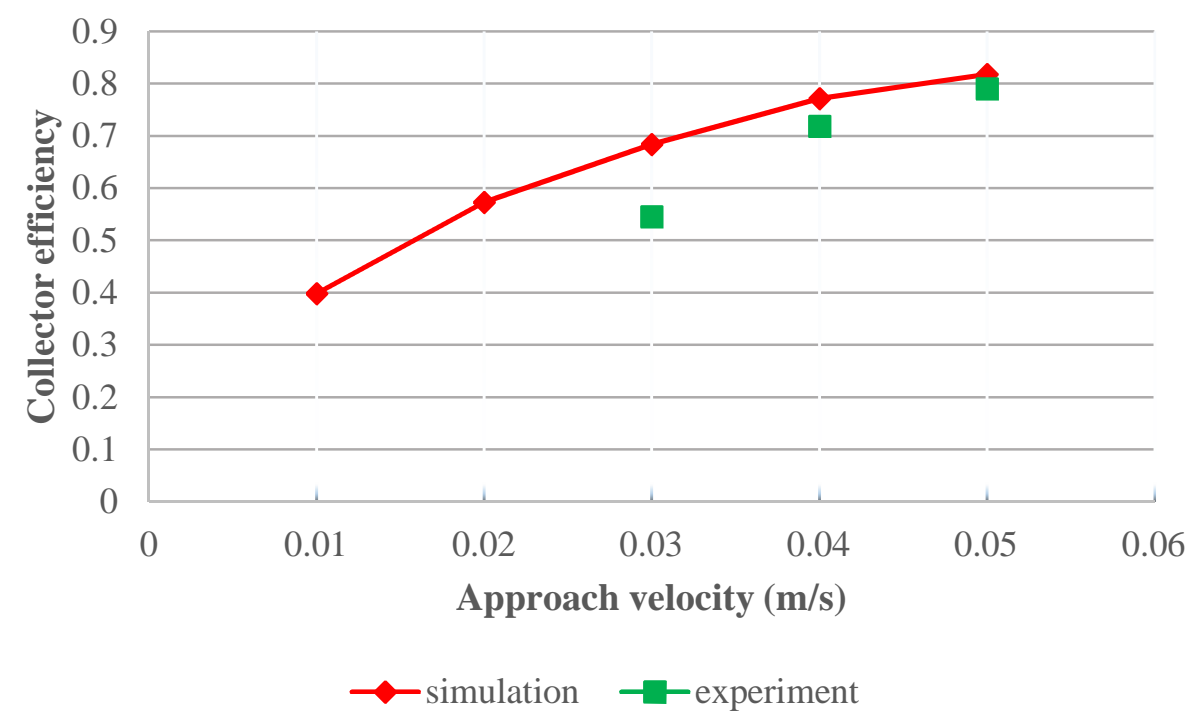

Fig. 20. Comparison of heat recovery efficiency between indoor testing and simulation

results

459 The outdoor experiment repeated the similar procedure in the indoor test and the results are

460 shown in Fig. 21. It could be found that the solar radiation level during testing was about $600-$

$461700 \mathrm{~W} / \mathrm{m}^{2}$, which was close to the one provided by solar simulator during indoor testing. The results illustrate that the PV temperature could only reach about $37^{\circ} \mathrm{C}$ under steady state condition, this is due to the low ambient temperature of $8^{\circ} \mathrm{C}$ and high wind speed of $2 \mathrm{~m} / \mathrm{s}$ on the outdoor testing day. In addition, it is important to mention that because the experiment was taken in winter, and the wind was strong and its speed was unstable during the test, the surface temperature of PV bounced up and down during the whole test. However, the general tendency of the temperature variation on PV cell was still available to demonstrate the effects by PV/T/D system. Therefore, the convective heat loss on the dielectric CPC panel exterior surface is much higher than that under the indoor testing condition $\left(15^{\circ} \mathrm{C}\right.$ and no wind). This could be proved by the difference of CPC surface temperature between indoor and outdoor testing results. However, similar to the indoor testing results, a clear increase in air outlet temperature and decrease in PV surface temperature could also be observed when the air suction fan was turned on. 


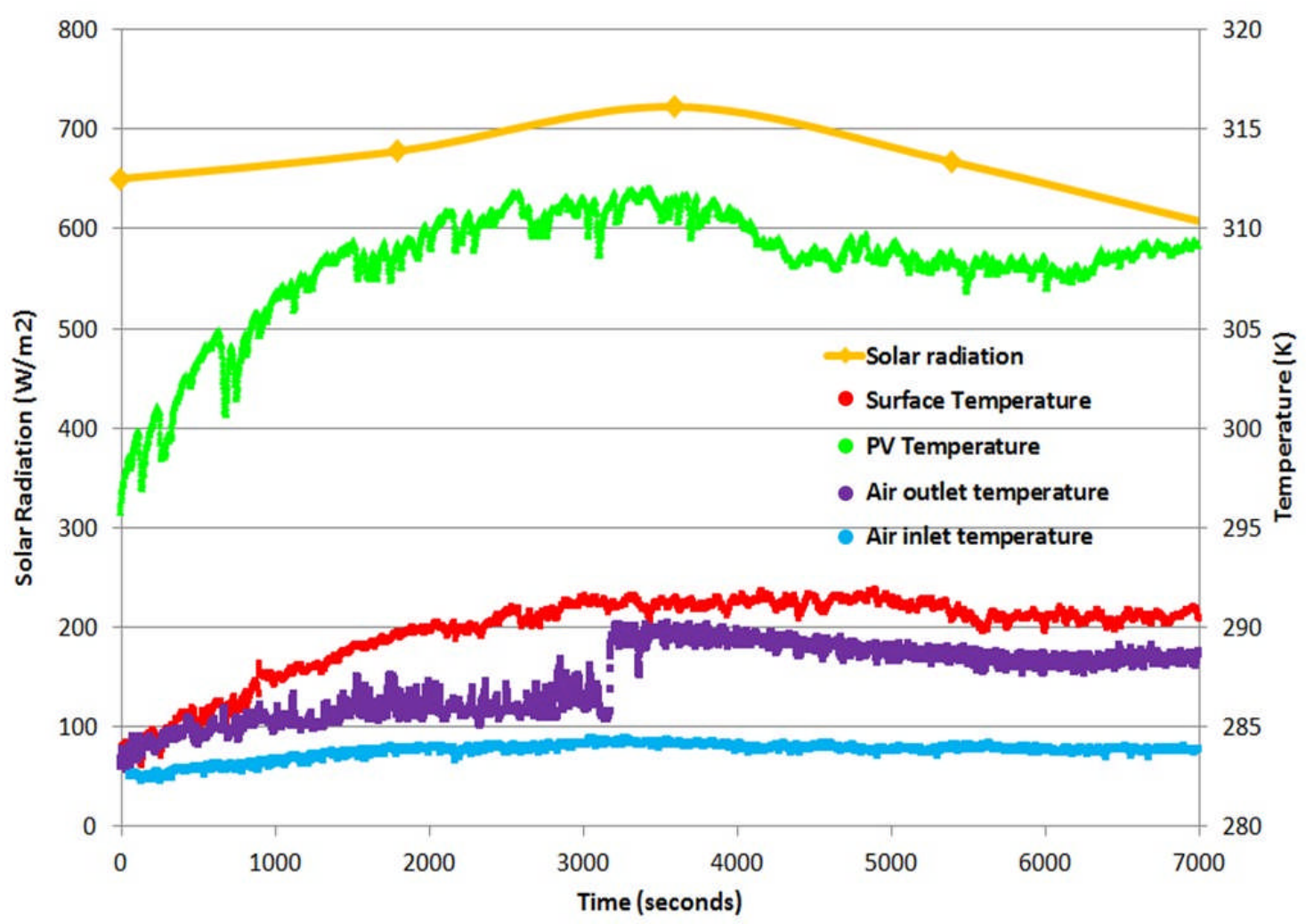

Fig. 21. Results of outdoor experiment

\section{Conclusion}

477

The air-based heat recovery system with perforation plate integrating dielectric CPC panel (PV/T/D system) was designed in this paper, which was inspired by the unglazed transpired solar air collector (UTC). The main aim of the design is, firstly and most importantly, to prevent heat rejection of PV cells on the base of CPC panel from transferring to the building interior; secondly, to remove heat rejection of PV cells so that the PV cell efficiency could be increased with lower surface temperature; and lastly, to collect and reutilise the rejected heat for other thermal application. As this system was designed as a skylight, it is expected to achieve multiple functions which are PV, thermal and daylighting. The designed PV/T/D system has been studied numerically using CFD simulation and experimentally under solar simulator and real sky condition.

The parametric study by CFD simulations has shown that different design parameters such as approach velocity, plenum height, pitch and perforation diameter, perforation porosity and solar radiation level could affect the collector thermal efficiency, PV cell temperature, temperature rise of collected air, and the amount of heat transferred to the atrium space, although the significances of the influences vary with different parameters. A good balance between the studied parameters in terms of air temperature rise, thermal collector efficiency and PV operating temperature needs to be established to achieve the best performance of $P V / T / D$ system. For experiments, both indoor and outdoor tests have shown that the main design objective of working as a heat recovery system could be achieved in the real condition. The simulation and experiment results present that the thermal efficiency of heat recovery system could range from $40 \%$ to $85 \%$, depending on different approach velocities and system geometries. And most importantly, this heat recovery system could largely reduce the amount 
499 of heat transferring from PV cells in the PV/T/D roof panel to the building interior so that the

500 effects on cooling load by heat rejection of PV cells could be largely mitigated.

501

502

Acknowledgements

503

The authors would like to thank the European Commission for the Marie Curie Fellowship

504 grants (PIIF-GA-2009-253945, PIIF-GA-2010-275038, H2020-MSCA-IF-2015-703746).

505

506

507 


\section{Reference}

ABDUL HAMID, S., YUSOF OTHMAN, M., SOPIAN, K. \& ZAIDI, S. H. 2014. An overview of photovoltaic thermal combination (PV/T combi) technology. Renewable and Sustainable Energy Reviews, 38, 212-222.

ARULANANDAM, S. J., HOLLANDS, K. G. T. \& BRUNDRETT, E. 1999. A CFD heat transfer analysis of the transpired solar collector under no-wind conditions. Solar Energy, 67, 93-100.

ATHIENITIS, A. K., BAMBARA, J., O'NEILL, B. \& FAILLE, J. 2011. A prototype photovoltaic/thermal system integrated with transpired collector. Solar Energy, 85, 139-153.

BADACHE, M., ROUSSE, D. R., HALLE, S. \& QUESADA, G. 2013. Experimental and numerical simulation of a two-dimensional unglazed transpired solar air collector. Solar Energy, 93, 209-219.

BARANOV, V. K. 1965. Properties of the Parabolico-theoric focons. Opt. Mekh. Prom., 6, 1-5.

BARANOV, V. K. 1966. Parabolotoroidal mirrors as elements of solar energy concentrators. Appl. Sol. Energy, 2, 9-12.

BARANOV, V. K. 1967. Device for Restricting in one plane the angular aperture of a pencil of rays from a light source (in Russian). Russian certificate of authorship 200530.

BARANOV, V. K. \& MELNIKOV, G. K. 1966. Study of the illumination characteristics of hollow focons. Sov. J. Opt. Technol., 33, 408-411.

BERGENE, T. \& L VVIK, O. M. 1995. Model calculations on a flat-plate solar heat collector with integrated solar cells. Solar Energy, 55, 453-462.

BROGREN, M., NOSTELL, P. \& KARLSSON, B. 2001. Optical efficiency of a PV-thermal hybrid CPC module for high latitudes. Solar Energy, 69, Supplement 6, 173-185.

BSI 2005. BS EN 13032-1:2004+A1:2012 Light and lighting. Measurement and presentation of photometric data of lamps and luminaires. Measurement and file format. UK: British Standards Institution.

CAO S, HOLLANDS KGT \& E, B. Heat exchange effectiveness of unglazed transpired-plate solar collector in 2D flow. ISES Solar World Congress, 1993 Budapest, Hungary. p.351.

CHOW, T. T., PEI, G., FONG, K. F., LIN, Z., CHAN, A. L. S. \& JI, J. 2009. Energy and exergy analysis of photovoltaic-thermal collector with and without glass cover. Applied Energy, 86, 310-316.

COLLINS, M. R. \& ABULKHAIR, H. 2014. An evaluation of heat transfer and effectiveness for unglazed transpired solar air heaters. Solar Energy, 99, 231-245.

FULIOTTO, R., CAMBULI, F., MANDAS, N., BACCHIN, N., MANARA, G. \& CHEN, Q. Y. 2010. Experimental and numerical analysis of heat transfer and airflow on an interactive building facade. Energy and Buildings, 42, 23-28.

GARG, H. P. \& ADHIKARI, R. S. 1999. Performance analysis of a hybrid photovoltaic/thermal (PV/T) collector with integrated CPC troughs. International Journal of Energy Research, 23, 1295-1304.

GUIQIANG, L., GANG, P., YUEHONG, S., YUNYUN, W. \& JIE, J. 2014. Design and investigation of a novel lens-walled compound parabolic concentrator with air gap. Applied Energy, $125,21-27$.

HALL, R., WANG, X., OGDEN, R. \& ELGHALI, L. 2011. Transpired solar collectors for ventilation air heating. Proceedings of the ICE-Energy, 164, 101-110.

HINTERBERGER, H., WINSTON, R. 1966a. Efficient light coupler for threshold Čerenkov counters. Review of Scientific Instruments, 37, 1094-1095.

HINTERBERGER, H., WINSTON, R. 1966b. Gas Čerenkov counter with optimized light-collecting efficiency. High Energy Phys., 205-206.

HOWLETT, G. 2015. Aging of light pipe materials (4000 hours artificial ageing). British Standards Institution Ltd. 
KUTSCHER, C. F. 1994. Heat Exchange Effectiveness and Pressure Drop for Air Flow Through Perforated Plates With and Without Crosswind. Journal of Heat Transfer, 116, 391399.

KUTSCHER, C. F., CHRISTENSEN, C. B. \& BARKER, G. M. 1993. Unglazed Transpired Solar Collectors - Heat-Loss Theory. Journal of Solar Energy Engineering-Transactions of the Asme, 115, 182-188.

LEON, M. A. \& KUMAR, S. 2007. Mathematical modeling and thermal performance analysis of unglazed transpired solar collectors. Solar Energy, 81, 62-75.

LI, G., PEI, G., YANG, M., JI, J. \& SU, Y. 2014. Optical evaluation of a novel static incorporated compound parabolic concentrator with photovoltaic/thermal system and preliminary experiment. Energy Conversion and Management, 85, 204-211.

LITTLEFAIR, P. \& TICLEANU, C. 2012. Testing of light tubes. British Research Establishment Ltd. LITTLEFAIR, P. J. \& GRAVES, H. M. 2008. Transmittance of large diameter light pipes under overcast and simulated sunlit conditions. Building Research Establishment Ltd.

NAEWNGERNDEE, R., HATTHA, E., CHUMPOLRAT, K., SANGKAPES, T., PHONGSITONG, J. \& JAIKLA, S. 2011. Finite element method for computational fluid dynamics to design photovoltaic thermal (PV/T) system configuration. Solar Energy Materials and Solar Cells, 95, 390-393.

NAVEED, A. T., KANG, E. C. \& LEE, E. J. 2006. Effect of Unglazed Transpired Collector on the Performance of a Polycrystalline Silicon Photovoltaic Module. Journal of Solar Energy Engineering, 128, 349-353.

PLOKE, M. 1967. Lichtführungseinrichtungen mit starker Konzentrationswirkung (English translation: A light guiding device with strong concentration action). Optik, 25, 31-43.

PLOKE, M. 1969. Axially Symmetrical Light Guide Arrangement.

RADZIEMSKA, E. 2003. The effect of temperature on the power drop in crystalline silicon solar cells. Renewable Energy, 28, 1-12.

SHUKLA, A., NKWETTA, D. N., CHO, Y. J., STEVENSON, V. \& JONES, P. 2012. A state of art review on the performance of transpired solar collector. Renewable and Sustainable Energy Reviews, 16, 3975-3985.

SUN, J. \& SHI, M. Experimental Study on A Concentrating Solar Photovoltaic/Thermal System. Power and Energy Engineering Conference (APPEEC), 2010 Asia-Pacific, 28-31 March $20102010.1-4$.

YU, X., SU, Y., ZHENG, H. \& RIFFAT, S. 2014. A study on use of miniature dielectric compound parabolic concentrator (dCPC) for daylighting control application. Building and Environment, 74, 75-85.

ZONDAG, H. A. 2008. Flat-plate PV-Thermal collectors and systems: A review. Renewable and Sustainable Energy Reviews, 12, 891-959. 